\title{
Kinematics and extent of the Piemont-Liguria Basin - implications for subduction processes in the Alps
}

\author{
Eline Le Breton $^{1}$, Sascha Brune ${ }^{2,3}$, Kamil Ustaszewski ${ }^{4}$, Sabin Zahirovic ${ }^{5}$, Maria Seton $^{5}$, and R. Dietmar Müller ${ }^{5}$ \\ ${ }^{1}$ Department of Earth Sciences, Freie Universität Berlin, Berlin, Germany \\ ${ }^{2}$ Geodynamic Modelling Section, German Research Centre for Geosciences, GFZ Potsdam, Potsdam, Germany \\ ${ }^{3}$ Institute of Geosciences, University of Potsdam, Potsdam, Germany \\ ${ }^{4}$ Institute for Geological Sciences, Friedrich-Schiller-Universität Jena, Jena, Germany \\ ${ }^{5}$ EarthByte Group, School of Geosciences, The University of Sydney, Sydney, NSW 2006, Australia
}

Correspondence: Eline Le Breton (eline.lebreton@fu-berlin.de)

Received: 18 September 2020 - Discussion started: 8 October 2020

Revised: 3 March 2021 - Accepted: 5 March 2021 - Published: 21 April 2021

\begin{abstract}
Assessing the size of a former ocean of which only remnants are found in mountain belts is challenging but crucial to understanding subduction and exhumation processes. Here we present new constraints on the opening and width of the Piemont-Liguria (PL) Ocean, known as the Alpine Tethys together with the Valais Basin. We use a regional tectonic reconstruction of the Western Mediterranean-Alpine area, implemented into a global plate motion model with lithospheric deformation, and 2D thermo-mechanical modeling of the rifting phase to test our kinematic reconstructions for geodynamic consistency. Our model fits well with independent datasets (i.e., ages of syn-rift sediments, riftrelated fault activity, and mafic rocks) and shows that, between Europe and northern Adria, the PL Basin opened in four stages: (1) rifting of the proximal continental margin in the Early Jurassic (200-180 Ma), (2) hyper-extension of the distal margin in the Early to Middle Jurassic (180-165 Ma), (3) ocean-continent transition (OCT) formation with mantle exhumation and MORB-type magmatism in the Middle-Late Jurassic (165-154 Ma), and (4) breakup and mature oceanic spreading mostly in the Late Jurassic (154-145 Ma). Spreading was slow to ultra-slow (max. $22 \mathrm{~mm} \mathrm{yr}^{-1}$, full rate) and decreased to $\sim 5 \mathrm{~mm} \mathrm{yr}^{-1}$ after $145 \mathrm{Ma}$ while completely ceasing at about $130 \mathrm{Ma}$ due to the motion of Iberia relative to Europe during the opening of the North Atlantic. The final width of the PL mature ("true") oceanic crust reached a maximum of $250 \mathrm{~km}$ along a NW-SE transect between Europe and northwestern Adria. Plate convergence along that same transect has reached $680 \mathrm{~km}$ since $84 \mathrm{Ma}(420 \mathrm{~km}$ between
\end{abstract}

84-35 Ma, $260 \mathrm{~km}$ between 35-0 Ma), which greatly exceeds the width of the ocean. We suggest that at least $63 \%$ of the subducted and accreted material was highly thinned continental lithosphere and most of the Alpine Tethys units exhumed today derived from OCT zones. Our work highlights the significant proportion of distal rifted continental margins involved in subduction and exhumation processes and provides quantitative estimates for future geodynamic modeling and a better understanding of the Alpine Orogeny.

\section{Introduction}

Over the last decades, new concepts on rifting processes, subduction initiation, and depth and exhumation of highpressure rocks during subduction have emerged. The Alps are a natural laboratory to test ideas as they have preserved a detailed record of rifted continental and ophiolite units derived from the Alpine Tethys that were accreted or subducted to ultra-high pressure and later exhumed at the surface (Froitzheim and Eberli, 1990; Froitzheim and Manatschal, 1996; Bernoulli and Jenkyns, 2009; Mohn et al., 2010; Beltrando et al., 2014; Masini et al., 2014). Studies of hyperextended magma-poor-type continental margins such as in the Alps have shed light on the tectonic complexities of distal and ocean-continental transition zones, along which various types of rocks such as granitoid basement within continental allochthons, serpentinized mantle rocks, gabbros, and basalts are put in contact by major detachment faults (e.g., 
Florineth and Froitzheim, 1994; Müntener and Hermann, 2001; Ferrando et al., 2004; Manatschal, 2004; Manatschal and Müntener, 2009; Epin et al., 2019). These zones of inherited weakness and thermal anomalies may represent ideal candidates for the localization of subduction initiation when plate motion becomes convergent (Beltrando et al., 2010; Tugend et al., 2014; Stern and Gerya, 2018; Kiss et al., 2020; Zhou et al., 2020).

Moreover, the Alpine chain is enigmatic due to its very arcuate plate boundaries and the switch of subduction polarity along strike (Fig. 1), the lack of a well-developed magmatic arc (e.g., McCarthy et al., 2018), and episodes of slab breakoff (e.g., Wortel and Spakman, 2000; Handy et al., 2015). Seismic tomography models beneath the Alps are thus difficult to interpret (see Kästle et al., 2020, for a recent review). Thermo-mechanical modeling is a key tool to gain a better understanding of orogenic processes in the Alps (e.g., Gerya et al., 2002; Yamato et al., 2007; Duretz et al., 2011; Ruh et al., 2015; Reuber et al., 2016; Spakman et al., 2018; Dal Zilio et al., 2020) and potentially a better interpretation of seismic tomography models. These geodynamic models, however, require quantitative input such as estimates of the former extent and thickness of the continental margins and oceanic domains involved in subduction, the paleo-location of plate boundaries through time, and the direction and rate of plate convergence. Kinematic reconstructions are thus crucial but challenging in such a tectonically complex area. First, regional geological reconstructions need to be globally connected and brought into a plate-mantle reference frame in order to assess mantle-plate-surface interactions through time (e.g., Müller et al., 2019). Second, there is growing debate that maximal burial depth of metamorphic rocks in subduction zones, as estimated from mineral phase equilibria and assuming lithostatic pressure, may be overestimated due to local overpressure and change in tectonic regime (Ford et al., 2006; Schmalholz and Podladchikov, 2013; Pleuger and Podladchikov, 2014; Reuber et al., 2016; Yamato and Brun, 2017; Moulas et al., 2019). This has significant implications for regional tectonic reconstructions that use an inferred amount of subduction based on peak depths of (ultra-)highpressure metamorphism (e.g., Schmid et al., 1996; Handy et al., 2010, 2015) and for conceptual models of the exhumation of high-pressure rocks (e.g., Brun and Faccenna, 2008).

The past extent and size of the Piemont-Liguria (PL) Ocean and its rifted margins, prior to the formation of the Alps, remain poorly constrained. Studies based on the age range of mafic rocks derived from the PL Ocean in the Alps and inferring ultra-slow spreading rates, propose a final extent ranging between $300 \mathrm{~km}$ (Li et al., 2013; Manzotti et al., 2014) and $500 \mathrm{~km}$ (Froitzheim and Manatschal, 1996; their Fig. 3) for the oceanic domain but lack kinematic constraints. Some kinematic models provide quantitative constraints on the amount of plate divergence, for example, $450 \mathrm{~km}$ between Iberia-Adria to $675 \mathrm{~km}$ between Europe-Adria in Vissers et al. (2013; their Fig. 7) and from ca. $500 \mathrm{~km}$ between Europe-
Adria to ca. $900 \mathrm{~km}$ between Sardinia-Adria in Handy et al. (2010; their Fig. 8b). However, those estimates do not distinguish between extended continental and oceanic domains. Thus, the aim of this paper is to provide robust kinematic constraints and address the question of how wide the PL Ocean and its rifted margin were, which is crucial to understanding slab pull forces, rollback, and the exhumation of high-pressure rock in the Alps. We furthermore discuss the style of rifting and extent of hyper-extended rifted margins versus mature oceanic domain (i.e., "true" oceanic, not transitional crust) that went into subduction during the formation of the Western and Central Alps. For this, we present one possible kinematic scenario for this area, based on a compilation of previously published models and an updated model for the past motion of Corsica-Sardinia. This regional reconstruction goes back to Triassic times and is implemented within the recent global plate model of Müller et al. (2019). Furthermore, we test this kinematic scenario for geodynamic consistency with thermo-mechanical modeling of the rifting phase and compare our results with existing geological records from the Alps.

\section{Geological setting}

The Alpine-Mediterranean belt results from a complex tectonic evolution that involved the closure of two oceans (Alpine Tethys and Neo-Tethys) and the subductioncollision of several continental domains (Briançonnais, Sesia, AlCaPa (standing for Alpine-Carpathians-Pannonian unit), Tisza, Dacia; Fig. 1) between two major plates - Eurasia and Africa - that have been converging since Cretaceous times (e.g., Dewey et al., 1989). The Adriatic plate (Adria) is a key player due to its central position between Eurasia and Africa. Today, Adria is surrounded by orogens: the Alps to the north, where Adria is the upper indenting plate; the Dinarides to the east and the Apennines to the west, where Adria is the subducting lower plate (Fig. 1). It is bounded to the south by the accretionary prism of the Calabrian Arc and the Kefalonia Fault (KF in Fig. 1).

The Alps contain the remains of two Jurassic- to Cretaceous-age basins (Piemont-Liguria and Valais) together referred to as the Alpine Tethys (e.g., Stampfli et al., 1998; Fig. 1) or, more recently, also as the "Alpine Atlantic" to emphasize its kinematic link with the Atlantic Ocean (Gawlick and Missoni, 2019). Here, however, we adopt the well-established term Alpine Tethys. In Cretaceous and Cenozoic times, the former Adriatic continental margin was accreted to the upper plate of the Alpine Orogen, represented today by the Austroalpine (part of "AlCaPa"; Fig. 1) and Southern Alpine units (south of the Periadriatic Line; Fig. 1). This upper plate also contains relics of an older ocean, the Neo-Tethys (also known as the MeliataMaliac-Vardar Ocean; Channell and Kozur, 1997; Schmid et al., 2008, 2020). The closure of Neo-Tethys, whose remnants 


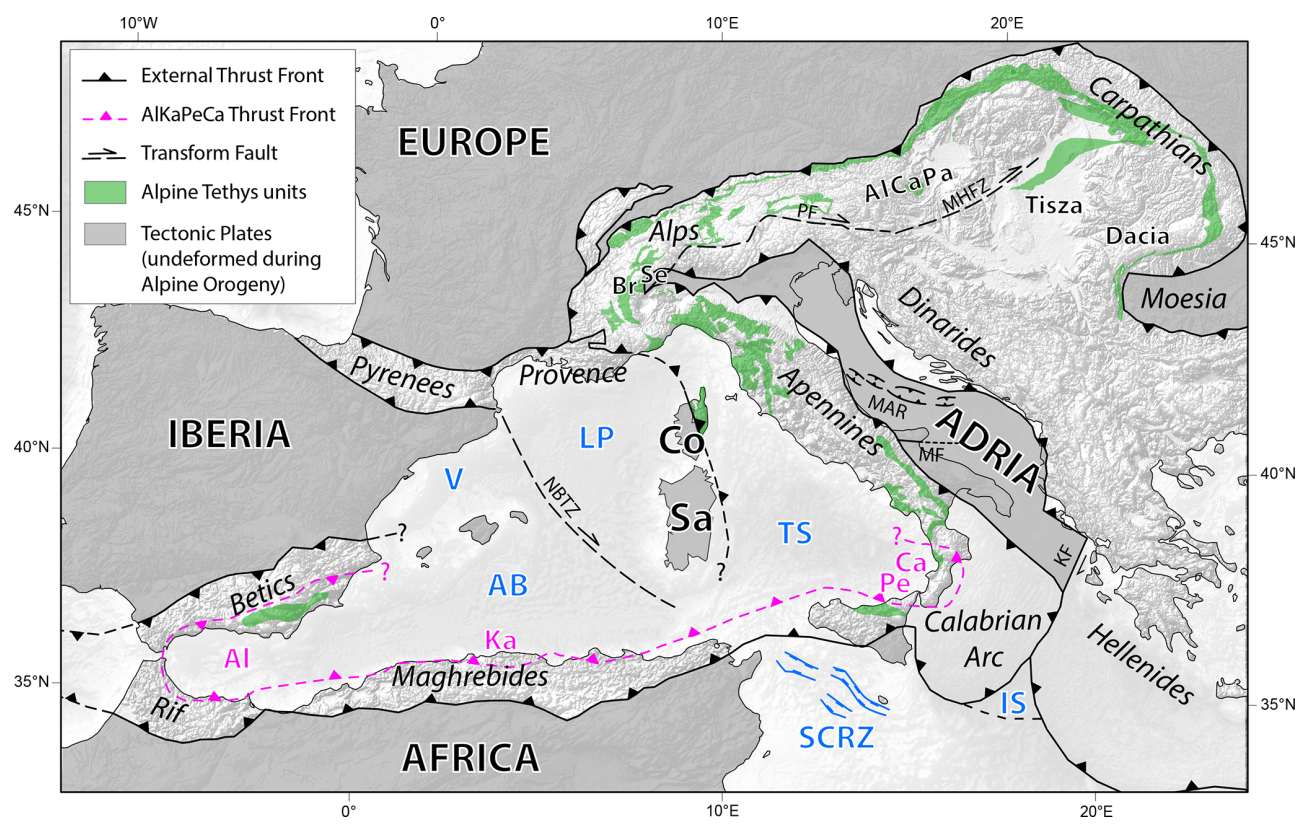

Figure 1. Simplified tectonic map of the Western Mediterranean-Alpine area (modified after Le Breton et al., 2017; Michard et al., 2006; Guerrera et al., 2019; Schmid et al., 2020). Location of Mattinata Fault (MF) from Argnani et al. (2009). Background topographicbathymetric map from the ETOPO1 model (Amante and Eakins, 2009). Abbreviations: AB - Algerian Basin; Al - Alboran; AlCaPa Alpine-Carpathians-Pannonian unit; Br - Briançonnais; Ca - Calabria; Co - Corsica; V - Gulf of Valencia; Ka - Kabylides; IS - Ionian Basin; KF Kefalonia Fault; LP - Liguro-Provençal Basin; MAR - Mid-Adriatic Ridge; MHFZ - Mid-Hungarian Fault zone; MF - Mattinata Fault; NBTZ - North Balearic Transform zone; Pe - Peloritani; PF - Periadriatic Fault; Sa - Sardinia; SCRZ - Sicily Channel rift zone; Se - Sesia; TS - Tyrrhenian Sea.

are found in abundance in the Dinarides (Vardar ophiolites), initiated in the Middle to Late Jurassic (age of metamorphic soles; Maffione and van Hinsbergen, 2018), coevally with rifting and spreading of the PL Ocean (Stampfli et al., 1998; Schmid et al., 2008). In the following sections we will focus on the evolution of the Alpine Tethys and of the Western and Central Alps. We note that remnants of the PL Ocean are also preserved in Miocene-to-recent nappes of the Apennines (including Calabria), the Betic Cordillera and Rif (southern Spain and northern Morocco), and the Maghrebides (northern Africa), as shown in Fig. 1 (AlKaPeCa units - AlboranKabylia-Peloritani-Calabria; Bouillin et al., 1986). Those nappes were emplaced during fast rollback of the subduction zone in the Cenozoic (e.g., Faccenna et al., 2001; Michard et al., 2002; Rosenbaum and Lister, 2004), triggering upperplate extension and the opening of the Western Mediterranean basins (Algerian Basin, Gulf of Valencia, LiguroProvençal Basin, and Tyrrhenian Sea; Fig. 1).

\subsection{Opening of the Alpine Tethys}

\subsubsection{The Piemont-Liguria Basin}

Tectono-stratigraphic, petrological, geochemical, and geochronological constraints from the Alps indicate that the PL margin represents a fossil example of a hyper-extended magma-poor continental margin, such as the Iberian margin today (e.g., Manatschal and Bernoulli, 1999; Manatschal, 2004; Decarlis et al., 2015). A first phase of rifting of the proximal part of the continental margin, with horst-andgraben structures bounded by high-angle faults, breccia deposits, and platform accumulations, took place in the Early Jurassic (ca. 200-180 Ma; e.g., Lemoine et al., 1986; Froitzheim, 1988; Froitzheim and Eberli, 1990; Conti et al., 1994; Froitzheim and Manatschal, 1996; Masini et al., 2013; Ribes et al., 2019). This was followed by the necking of the continental lithosphere, with the development of crustalscale extensional detachment faults (Mohn et al., 2012; Ribes et al., 2019), and hyper-extension of the distal part of the margin between ca. 180 and $165 \mathrm{Ma}$, characterized by both low- and high-angle normal faults, the detachment of continental allochthons, and the exhumation of mantle rocks (e.g., Froitzheim and Eberli, 1990; Froitzheim and Manatschal, 1996; Masini et al., 2013; Ribes et al., 2019). Transects across the proximal to distal parts of the former Adriatic margin are well preserved in the Southern Alps and Austroalpine units of the Central and Eastern Alps (Mohn et al., 2012, their Fig. 2; Ribes et al., 2019). For example, in the Central Alps, the record of the proximal Adriatic margin is observed within the Ortler and Ela units, the necking domain within the Campo-Grosina and Languard units, the hyper-extended domain within the Bernina and Err units, and the exhumed mantle domain within the upper and lower 
Plata units (Froitzheim and Manatschal, 1996; Mohn et al., 2010; Ribes et al., 2019).

Radiolarite sedimentation started at around $166 \pm 1 \mathrm{Ma}$ (Bill et al., 2001) covering both oceanic rocks and adjacent distal margins, which suggests post-rift sedimentation and used to be interpreted as continental breakup around that time. However, Ribes et al. (2019) showed a diachroneity in the post-rift sedimentation, younging from the proximal to the distal exhumed mantle domain of the passive margin system. Indeed, extension related to final rifting in the most distal part of the magma-poor margin along the oceancontinent transition (OCT) often leads to the juxtaposition of extremely diverse types of rock such as slices of continental crust in contact with exhumed serpentinized mantle, pelagic sediments, gabbros, and basalts (e.g., Florineth and Froitzheim, 1994; Froitzheim and Manatschal, 1996; Hermann and Müntener, 1996; Marroni et al., 1998; Müntener and Hermann, 2001; Ferrando et al., 2004; Manatschal et al., 2006; Manatschal and Müntener, 2009; Epin et al., 2019; Ribes et al., 2020). Some Alpine Tethys ophiolites are interpreted as representing former OCT rather than the mature PL Ocean, due to the presence of exhumed mantle and detachment faults associated with tectono-sedimentary breccias (Manatschal and Müntener, 2009). U-Pb ages on zircons from MORB-type gabbros and plagiogranites from Corsica, the Northern Apennines, and the Alps give a range from ca. 165 to $140 \mathrm{Ma}$ (Bortolotti and Principi, 2005; Manatschal and Müntener, 2009; their Fig. 6 and references therein), dating both the OCT formation and mature oceanic spreading. The juxtaposition of pillow lavas directly with mantle rocks and the lack of sheeted dikes in the Alpine Tethys ophiolites (e.g., Barrett and Spooner, 1977; Lagabrielle and Cannat, 1990; Lagabrielle and Lemoine, 1997; Decrausaz et al., 2021) indicate an ultra-slow type of spreading for the PL Ocean.

Parts of the continental European margin are preserved in the Alps within the Helvetic and Penninic nappes. Another extended continental unit, the Briançonnais, was detached from Europe during the opening of another basin: the Valais Basin.

\subsubsection{The Valais Basin}

The opening of the Valais Basin separated the Briançonnais continental unit from the European Plate (e.g., Stampfli, 1993). This is supported by the Early Cretaceous tectonostratigraphic record between the Briançonnais and Valais domains (Florineth and Froitzheim, 1994) and the so-called "Valaisan trilogy" (Trümpy, 1951, 1954; Loprieno et al., 2011), whose oldest stratigraphic unit (Aroley Formation) is dated to the Barremian-Aptian (130-110 Ma).

Based on $\mathrm{U}-\mathrm{Pb}$ zircon dating on metabasic rocks of the Valais domain, Liati et al. (2005) and Liati and Froitzheim (2006) proposed that the Valais Basin was floored by two generations of oceanic crust and resulted from "re-rifting" of oceanic crust that first formed during the opening of the PL Ocean at about 165-155 Ma and secondly during the opening of the Valais Ocean at about 93 Ma. The existence of a Valais "Ocean" was, however, disputed by Masson et al. (2008), who dated the ophiolites of this domain to the early Carboniferous (U-Pb age). Beltrando et al. (2007) also showed evidence for Permian $\mathrm{U}-\mathrm{Pb}$ zircon ages, with only a few Cretaceous ages (110-100 Ma) in the rims of some zircons, interpreted as a thermal and fluid event related to extension rather than spreading. The characteristics of a hyper-extended margin and OCT zone, with mantle exhumation and limited magmatic activity within the Valais Basin, were later described by Beltrando et al. (2012). Moreover, the presence of significant sedimentation pre-dating the onset of the Valaisan trilogy (Loprieno et al., 2011; Beltrando et al., 2012) confirmed the hypothesis of a multi-stage opening, as proposed by Liati et al. (2005).

Following these observations, we conclude that the Valais Basin was not a mature oceanic basin but a re-rifted, hyperextended continental margin with exhumed mantle and a few magmatic rocks (OCT zone) that rifted away from Europe first during the opening of the PL Basin in the Jurassic but mainly during the Cretaceous. Late Aptian-Albian extensional basins, with turbiditic and basinal series including olistoliths and breccias, associated with sinistral fault zones are also recorded in Provence (e.g., Joseph et al., 1987; Montenat et al., 2004) and in the Pyrenees (e.g., Debroas, 1990; Choukroune, 1992). The potential kinematic link between rifting in the Pyrenees-Provence area and the Valais Basin in the Cretaceous is discussed in Sect. 3.

\subsection{Closure of the Alpine Tethys}

Following tectono-stratigraphic and geochronological studies on syn-orogenic sediments, high-pressure metamorphic rocks, and thrust sheets in the Alps (e.g., Froitzheim et al., 1996; Stampfli et al., 1998; Schmid et al., 2008; Handy et al., 2010, 2015), the closure of the Alpine Tethys can be summarized in three stages:

1. Nappe stacking of continental units and high-pressure metamorphism were first recorded in the Eastern Alps, indicating an intracontinental subduction zone within Adria (Austroalpine unit, part of $\mathrm{AlCaPa}$; Stüwe and Schuster, 2010) which developed possibly along Late Jurassic strike-slip faults connected to the western termination of the Neo-Tethys Ocean (Schuster and Frank, 1999; Frank and Schlager, 2006). This phase corresponds to the "Eo-Alpine" Orogeny and occurred between ca. 130-84 Ma (Faupl and Wagreich, 1999), as indicated by both syn-orogenic clastics (Rossfeld Formation; Faupl and Tollmann, 1979) and geochronological data on high-pressure metamorphic rocks within the Austroalpine units of the Eastern Alps (e.g., Thöni, 2006; Manzotti et al., 2014, their Fig. 5 and references therein). Regional-scale sinistral strike-slip faults off- 
setting Austroalpine units were also active during Cretaceous times and were potentially related to the opening of the North Atlantic and subsequent motion of Iberia relative to Europe (Neubauer et al., 1995; Sieberer and Ortner, 2020).

2. South or southeast-directed "Alpine" subduction of the PL Ocean, the Valais Basin, and the distal European continental margin followed from ca. 84 to $35 \mathrm{Ma}$. The subduction initiated at the Adriatic margin (Sesia, ca. 85-65 Ma) and progressed from southeast to northwest across the PL Ocean (ca. 50-45 Ma), the Briançonnais (ca. 45-42 Ma), and the Valais Basin (ca. 42-35 Ma) as indicated by the tectono-metamorphic evolution of those units (e.g., Rubatto et al., 1998; Manzotti et al., 2014, 2018; Handy et al., 2010). The subduction phase is also dated by syn-orogenic trench fill (flysch) sediments, which began at ca. 94-86 Ma in the PL Ocean and ca. $70 \mathrm{Ma}$ in the Valais Basin and ended at ca. 35-32 Ma (Matter et al., 1980). Relics of this Alpine subduction and highly metamorphic rocks with ages ranging from $84 \mathrm{Ma}$ (Lahondère and Guerrot, 1997) to $35 \mathrm{Ma}$ (Martin et al., 2011) are also found in NE Corsica (Alpine Corsica; Fig. 1; Molli, 2008). North of Corsica, east-west-trending thrusts and folds, associated with syn-tectonic foreland sedimentation also started in the uppermost Santonian (ca. $83 \mathrm{Ma}$ ) in Provence (e.g., Espurt et al., 2012) and continued until the Eocene (e.g., Lacombe and Jolivet, 2005; Andreani et al., 2010). This shortening phase in Provence is related to the formation of the Pyrenees to the west, which initiated at about $83 \mathrm{Ma}$ (e.g., Mouthereau et al., 2014).

3. Collision in the Alps and "Apennine" rollback subduction of the remaining PL Ocean and Ionian Basin initiated at about $35 \mathrm{Ma}$. The exact timing of the onset of collision in the Alps differs depending on the criteria used. For instance, continental units, such as the abovementioned Briançonnais, entered the trench and were subducted prior to $35 \mathrm{Ma}$. However, here we distinguish continental subduction, in which rifted and thinned continental lithosphere behaves similarly to oceanic lithosphere, from continental collision, where slab pull is outweighed by the positive buoyancy of the (less rifted) continental lithosphere following slab break-off and detachment of the subducted lithosphere. Timing of slab break-off in the Alps is inferred from timing of magmatism along the Periadriatic Line, mainly between 34-28 Ma (Rosenberg, 2004). Indeed, the geochemistry of these magmatic rocks indicates the melting of lithospheric mantle, best explained by a slab breakoff event (von Blanckenburg and Davies, 1995). Moreover, this time period (35-30 Ma) is also marked by a change in sedimentation from flysch to molasse ( $\mathrm{Ru}-$ pelian Lower Marine Molasse, 33.9-28.1 Ma) in the Alpine Foreland basin (Matter et al., 1980; Sinclair,
1997) and the onset of medium-temperature-mediumpressure Barrovian-type metamorphism within the orogen (Lepontine Dome, Tauern Dome; e.g., Bousquet et al., 2008) attributed to the thickening of the European crust (Venediger Duplex formation in the Tauern Window; Scharf et al., 2013b). Thus, $35 \mathrm{Ma}$ appears to be a reasonable time for the onset of collision in the Alps, as defined above. In Provence, Oligocene extensional tectonics started at about $35 \mathrm{Ma}$ in response to rollback of the Apennine subduction (e.g., Séranne, 1999). In the Carpathians, the eastward continuation of the Alps and eastward retreat of the subduction began in early Miocene times (e.g., Horváth et al., 2006), contemporaneously with collision of the Adriatic Plate with Europe and lateral extrusion in the Eastern Alps (e.g., Ratschbacher et al., 1991; Scharf et al., 2013a). Rollback subduction was compensated for by upper-plate extension (Pannonian Basin) and arcuation (Ustaszewski et al., 2008) and involved little convergence between Europe and Adria (Royden and Burchfiel, 1989).

\section{Kinematic reconstructions of the Alpine-Mediterranean area}

\subsection{Approach}

Reconstructing the past motion of the Alpine-Mediterranean area is challenging due to the broad deformation, especially around the Adriatic Plate (Fig. 1). Our approach is thus to reconstruct the tectonic deformation that affected the plates during the Alpine Orogeny, with a focus on Adria and Sardinia-Corsica, to quantify the amount of divergence and convergence between stable parts of each plates, i.e., those not deformed during the Alpine Orogeny (in grey in Fig. 1). To do so, we compile existing kinematic reconstructions and geological-geophysical data from the surrounding orogens (Alps, Provence, Apennines, Dinarides) and basins (Western Mediterranean basins, Ionian Sea - Fig. 2; see more details on the method in Le Breton et al., 2017, for Neogene times). The motion of Europe, Iberia, and Africa is obtained from previously published reconstructions that fit conjugate magnetic anomalies in the Atlantic and restore the rifting history of the continental margins. This step is crucial to providing a global frame for the regional reconstructions of the Alpine area. Major tectonic events are dated by syn-tectonic sediments, magmatic and metamorphic rocks, and magnetic anomalies in the Atlantic Ocean (magnetochronostratigraphy), which allow us to draw tectonic maps at key times of the evolution of the Alpine Tethys (rifting and spreading) and Alpine Orogeny (subduction and collision). We then use GIS software (e.g., ArcGIS) and GPlates (https://www.gplates.org, last access: 12 April 2021, Müller et al., 2018) to digitize the tectonic maps, calculate rotation 
poles when needed, and obtain a kinematic model back to 200 Ma. Moreover, GPlates (version 2.2) has the functionality to build plate motion models with continuously evolving topologies for rigid and deforming plates and to include deformation both within the plates and along their boundaries (Gurnis et al., 2012, 2018; Müller et al., 2019). We are thus able to model the evolution of the deforming Adriatic Plate and the strong arcuation of its boundaries especially during the fast slab rollback and trench retreat in Cenozoic times (Faccenna et al., 2001; Rosenbaum and Lister, 2004).

The workflow between the geological reconstructions (tectonic maps) and GPlates is based on an iterative approach (Fig. 2). The tectonic reconstructions give us a range of possible amount of convergence or divergence between the plates, and the kinematic reconstructions with GPlates allow us to visualize misfits in our tectonic reconstructions, i.e., overlaps between stable parts of the plates, and thus indicate "problematic" areas in our tectonic maps that should be further studied. This approach is a never-ending endeavor as new geological and geophysical data from the AlpineMediterranean and the Atlantic are constantly being produced and/or are the subject of debated interpretations. Thus, after a brief description of the existing debates and potential scenarios, we present our current "best-fit" model for the Western Mediterranean-Alpine area and the main assumptions on which it relies. Our regional model for the Western Mediterranean-Alpine area is part of the global plate model of Müller et al. (2019), and all reconstructions and rotation files are available at https://www.earthbyte.org/webdav/ftp/ Data_Collections/Muller_etal_2019_Tectonics/ (last access: 12 April 2021).

\subsection{Existing kinematic scenarios and debates}

Due to the complexity of the Alpine-Mediterranean area and based on different datasets and assumptions, several kinematic scenarios back to Mesozoic times have been proposed (e.g., Le Pichon et al., 1988; Dewey et al., 1989; Srivastava et al., 1990; Rosenbaum et al., 2002; Stampfli and Borel, 2002; Handy et al., 2010; Schettino and Turco, 2011; Van Hinsbergen et al., 2020). A key player in the reconstruction of the Western Mediterranean area is Iberia. Its exact position in Mesozoic times - prior to spreading and clear magnetic anomalies such as the chron C34 $(83.5 \mathrm{Ma}$; Macchiavelli et al., 2017) - is highly debated depending on the interpretation of paleomagnetic studies on land, magnetic anomalies in the Atlantic, and geological-geophysical data from the Pyrenees. Two end-member kinematic scenarios for the Mesozoic motion of Iberia have been proposed: (1) transtensional eastward motion of Iberia versus Europe (e.g., Le Pichon et al., 1988; Olivet, 1996; Stampfli and Borel, 2002; Jammes et al., 2009; Handy et al., 2010; Schettino and Turco, 2011; Barnett-Moore et al., 2018) and (2) scissor-style opening of the Bay of Biscay and rotation of Iberia in Lower Cretaceous times (Sibuet et al., 2004; Vissers and Meijer, 2012; Vissers et al., 2016a; van Hinsbergen et al., 2020). The main difference is that (1) implies transtension (or strike-slip followed by orthogonal extension; Jammes et al., 2009) in the Pyrenees in the Early Cretaceous, whereas (2) involves subduction and slab break-off in the Pyrenees during that same time period (130-110 Ma).

Another topic discussed is the potential kinematic link between the opening of the Bay of Biscay, the motion of Iberia, and the opening of the Valais Basin along a major transtensional zone, which would follow the abovementioned endmember (1) for Iberia (e.g., Frisch, 1979; Stampfli, 1993; Stampfli and Borel, 2002; Handy et al., 2010). This kinematic link is mostly based on the synchronous time of the opening of the Bay of Biscay (Tugend et al., 2014), sinistral transtensional deformation in the Pyrenees (Peybernés and Souquet, 1984; Choukroune, 1992; Oliva-Urcia et al., 2011; Canérot, 2017) and in Provence (Bestani et al., 2015, and references therein), and the main opening phase of the Valais Basin (Sect. 2.1.2) in Early Cretaceous times. Handy et al. (2010) furthermore proposed that this sinistral motion was kinematically linked further to the east to the Eo-Alpine Orogeny (ca. 130-84 Ma; Sect. 2.2). This view is however refuted by a model based on paleomagnetic data from Sardinia, which indicates an independent rotation of Sardinia compared to Iberia (Advokaat et al., 2014). This led to the proposition of an alternative kinematic scenario, in which Sardinia-Corsica remains close to its present-day location with respect to the European Plate, and the opening of the Valais is kinematically independent from the motion of Iberia (Van Hinsbergen et al., 2020).

Complex late-stage rift processes along the magma-poor Iberian margin led to a wide continent-ocean transition zone and to debate on the nature of the M0 magnetic anomaly or "J" anomaly in the North Atlantic (Bronner et al., 2011; Tucholke and Sibuet, 2012; Nirrengarten et al., 2017) used to constrain the motion of Iberia in a scissor-style way in the Early Cretaceous (end-member model (2) for Iberia; Sibuet et al., 2004; Vissers and Meijer, 2012; van Hinsbergen et al., 2020). Additionally, the paleomagnetic dataset in Iberia that indicates a counterclockwise rotation by $35^{\circ}$ of Iberia in the Early Cretaceous (Vissers and Meijer, 2012; van Hinsbergen et al., 2020) is subject to an active debate (Neres et al., 2012, 2013; see also discussion of Barnett-Moore et al., 2016, 2017, and van Hinsbergen et al., 2017). Most importantly, the scissor-style motion of Iberia and the alternative model for Sardinia mentioned above (Advokaat et al., 2014; Van Hinsbergen et al., 2020) imply subduction in the Pyrenees but also of significant part of the PL Ocean between Iberia and Sardinia-Adria between 130-110 Ma (Fig. 3, 1.A). However, geological records in the Pyrenees, i.e., thick (up to $5 \mathrm{~km}$ ) Albo-Cenomanian sedimentary faultrelated basins (turbidites and breccias) later inverted during the Pyrenean Orogeny as well as the exhumation of (ultra)mafic rocks and Cretaceous alkali magmatism, all lead towards the interpretation of a rifting phase rather than sub- 

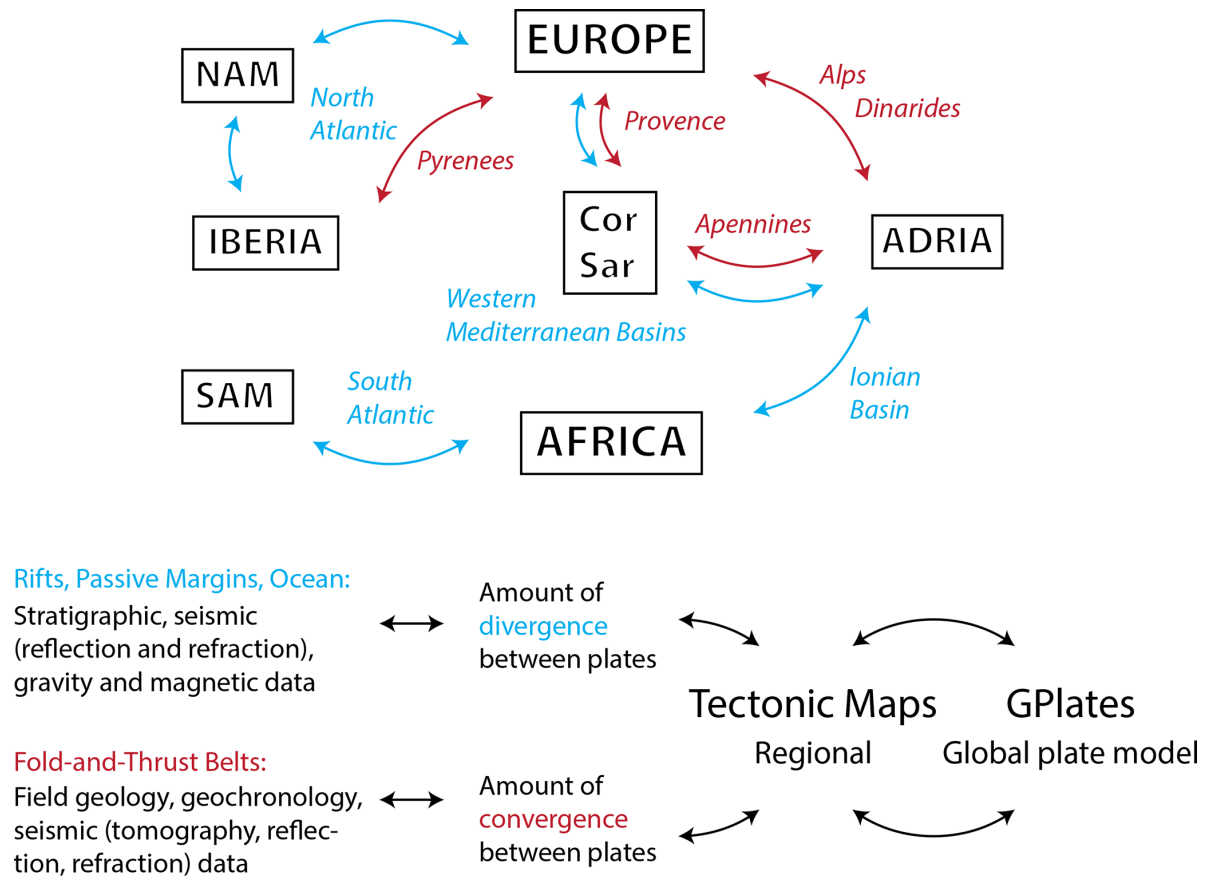

Figure 2. Approach and data used in this study to estimate the amount of deformation between plates in the Western Mediterranean-Alpine area and reconstruct their past plate motions within a global frame using GPlates. Abbreviations: Cor - Corsica; NAM - North America; Sar - Sardinia; SAM - South America.

duction in Early Cretaceous times (e.g., Jammes et al., 2009; Clerc and Lagabrielle, 2014; Masini et al., 2014; Tugend et al., 2014). The transition from divergence to convergence is dated later by the inversion of rift faults and syn-inversion growth strata of late Santonian age (at around $84 \mathrm{Ma}$; e.g., McClay et al., 2004; Mouthereau et al., 2014), which fits in with the onset of Alpine subduction further east (Sect. 2.2) and the Late Cretaceous age of syn-orogenic flysch sediments in the Alps (Matter et al., 1980) and Northern Apennines (Marroni et al., 1992).

Figure 3 summarizes what we call the "Iberia-Sardinia Problem" (Fig. 3.1), and following the abovementioned geological record of transtension or extension in the Pyrenees and the absence of geological evidence for convergence between Iberia and Sardinia in the Early Cretaceous, we favor the kinematic model involving sinistral transtensional motion between Europe and Iberia, linked to the opening of the Valais Basin and Eo-Alpine Orogeny to the east (Fig. 3, 1.B). We emphasize here that this motion is post-145 Ma (Tugend et al., 2014; Barnett-Moore et al., 2018) and thus does not influence the opening of the PL Basin, which occurs earlier in the Jurassic (Sect. 2.1.1). The implications of a possible earlier phase of Jurassic rifting in the Pyrenees, as suggested by Jurassic ages of pyroxenites (Henry et al., 1998) and shear zones at Cap de Creus (Vissers et al., 2016b), is discussed in Sect. 5.2.

\subsection{Reconstructions of the Atlantic (Europe, Africa, Iberia)}

The motion of Europe, Africa, and Iberia is well constrained by the fit of conjugate magnetic anomalies that formed during seafloor spreading along the mid-Atlantic ridge (Müller et al., 1997, 1999, for the fit of South and North Americas vs. Africa; Gaina et al., 2002, and Schettino and Scotese, 2005, for North America vs. Europe and Iberia, respectively). For the pre-breakup phase, the global plate model of Müller et al. (2019) is built on the reconstructions of Kneller et al. (2012) for the central Atlantic, Heine et al. (2013) for the South Atlantic, and Barnett-Moore et al. (2018) for the North Atlantic. Those models are based on structural restoration of the conjugate Atlantic margins using the rift basin architecture and present-day crustal thickness to approximate the amount and direction of extension and also of intracontinental rift basins in Africa and South America (Heine et al., 2013). We note that the model used for Iberia (Barnett-Moore et al., 2018) follows the favored model of transtensional motion rather than subduction between Iberia and Europe in the Early Cretaceous (see Sect. 2.3).

\subsection{Reconstructions of Adria and Sardinia-Corsica}

Another key player in the geodynamic evolution of the Alpine-Mediterranean area is the past motion of the Adriatic Plate (Adria). In most models, Adria is regarded as a "promontory" of Africa (Channell et al., 1979) and thus is 


\section{1 - The Iberia-Sardinia Problem}

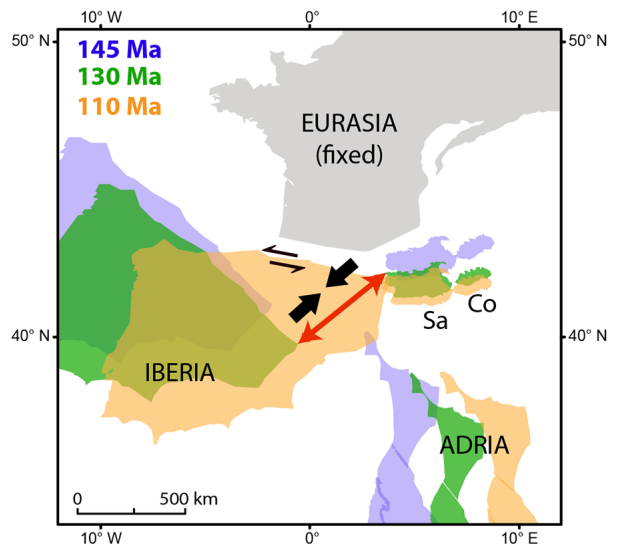

1.A. Sardinia-Corsica as part of European plate: Model for Iberia and Sardinia in accordance with paleo-magnetic data (from van Hinsbergen et al., 2020) $\Rightarrow>$ implies convergence between Iberia and Sardinia (500-700 km depending on kinematic model used for Iberia) mostly in Lower Cretaceous (130-100 Ma)

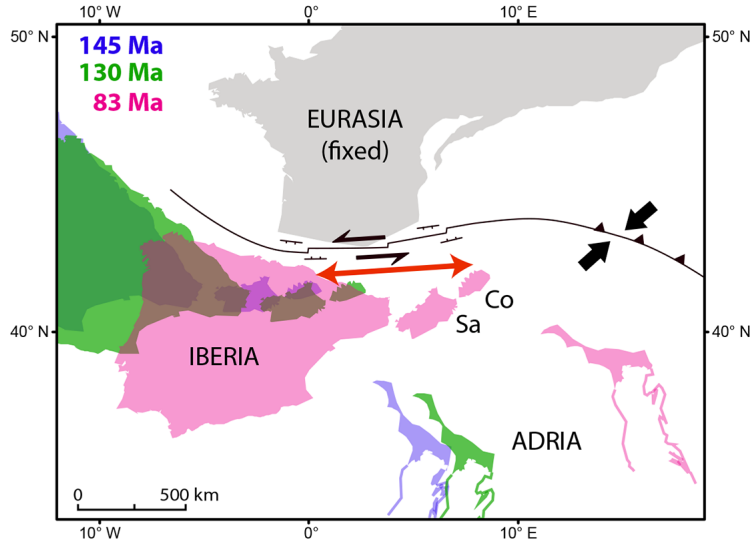

1.B. Sardinia-Corsica as part of Iberian plate: Alternative model where motion of Iberia-Sardinia-Corsica is accommodated by sinistral motion (up to $700 \mathrm{~km}$ between 145 and $84 \mathrm{Ma}$ ) and kinematically linked with opening of the Valais Basin and intra-continental Eo-Alpine orogeny within Adria to the East (as proposed, e.g., by Handy et al., 2010)

\section{2 - The Adria Problem}

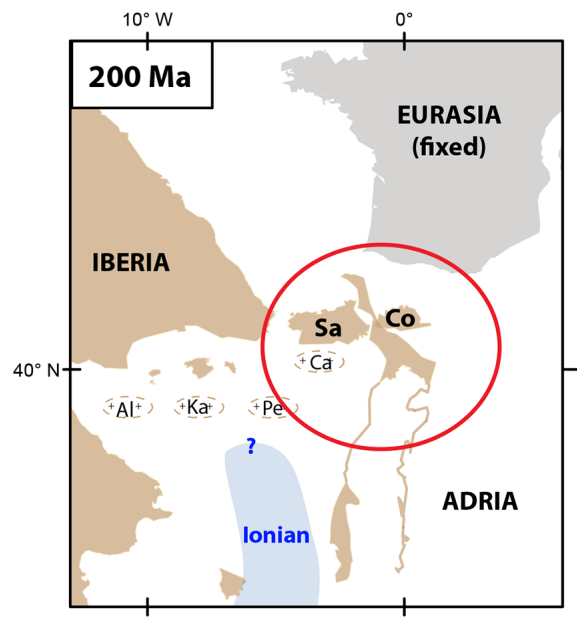

2.A. Adria - 1 single plate:

Overlap between Northern Adria and Corsica-Sardinia

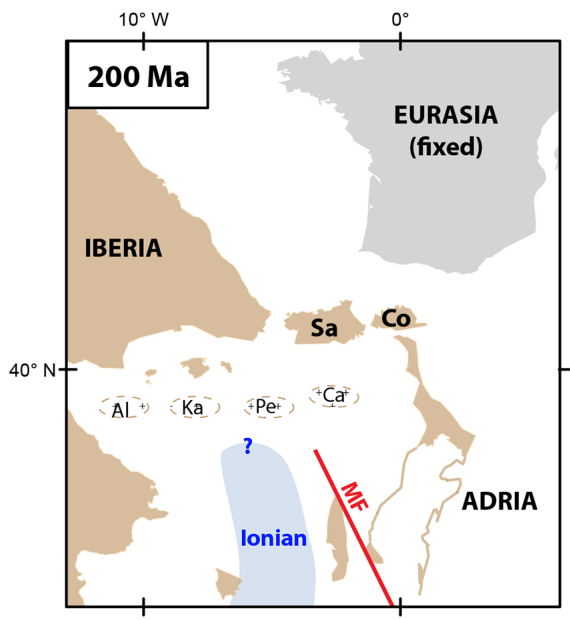

2.B. Adria - 2 plates:

Split of Adria along Mattinata Fault (MF) to avoid overlap with Corsica-Sardinia

$=>$ Implies in return ca. $230 \mathrm{~km}$ sinistral motion along MF in Cretaceous-Paleogene times (as proposed by Schettino and Turco, 2011)

Figure 3. (1) Contrasting paleo-reconstructions of Iberia and Sardinia-Corsica at $145 \mathrm{Ma}$ (blue), $130 \mathrm{Ma}$ (green), $110 \mathrm{Ma}$ (orange), and $83 \mathrm{Ma}$ (purple) relative to Eurasia: 1.A model in accordance with paleomagnetic data (from van Hinsbergen et al., 2020) but implying more than $500 \mathrm{~km}$ convergence between Iberia and Sardinia in the Lower Cretaceous (130-110 Ma), of which there is no geological record; 1.B alternative model considering Sardinia-Corsica as part of Iberian plate and implying an up to $700 \mathrm{~km}$ strike-slip (transtensional) motion along the North Pyrenean Fault. In the latter model, the convergence relative to Eurasia is accommodated more to the east, along the Eo-Alpine Orogeny, as proposed, e.g., by Handy et al. (2010). (2) Contrasting paleo-reconstructions of Adria following model 1.B, at $200 \mathrm{Ma}$, prior to the opening of the Piemont-Liguria Basin. The left model (2.A) shows the "overlap" problem between northern Adria and Sardinia-Corsica when reconstructing Adria as a single plate. This is solved in the right model (2.B) by subdividing Adria into two plates along the Mattinata Fault (MF; Fig. 1) as proposed by Schettino and Turco (2011). See text for further explanations. Abbreviations: Al - Alboran; Ca - Calabria; Co - Corsica; Ka - Kabylides; Pe - Peloritani; Sa - Sardinia. 
restored as moving together with Africa, since the end of the opening of the Ionian Basin. The kinematics and opening of this basin are difficult to constrain, as most of it was lost to subduction and the small remaining portion is covered by the Calabrian accretionary prism today (Fig. 1). Seismic refraction and reflection data indicate that the Ionian basin is floored by oceanic crust (Dannowski et al., 2019) and magnetic anomalies indicate an early Mesozoic age of spreading (220-230 Ma; Speranza et al., 2012). Handy et al. (2010), using tectonic reconstructions of the Alps, proposed an independent motion of the Adriatic Plate since $84 \mathrm{Ma}$, which in turn would imply significant deformation in the Ionian Basin. However, there is no geological evidence for such deformation within this basin. Only the Sicily Channel rift zone (SCRZ; Fig. 1) records an extensional event and accommodates some divergence between Africa and Adria, but only in Neogene times and of a limited amount $(30 \mathrm{~km}$ minimum along the Pantelleria Rift, CROP M25; Civile et al., 2010; Le Breton et al., 2017). Moreover, this extensional phase might not be directly related to plate kinematics but rather to the dynamics of the subducted African slab (Argnani, 2009).

The Neogene tectonic evolution of Adria and SardiniaCorsica is constrained by reconstructing the amount of convergence along fold-and-thrust belts (Apennines, Alps, Dinarides for Adria; Provence for Sardinia-Corsica) and coeval divergence along extensional basins (Liguro-Provençal and Tyrrhenian basins, Sicily Channel rift zone) (Le Breton et al., 2017). Those reconstructions show that Adria had a slightly independent motion from Africa and has rotated counterclockwise by about $5^{\circ}$ relative to Europe since $20 \mathrm{Ma}$. As mentioned above, the Ionian Basin between Africa and Adria is oceanic (seismic velocities; Dannowski et al., 2019) and opened in the Triassic (220-230 Ma, based on magnetic anomalies; Speranza et al., 2012). Thus, our main assumption is to avoid any significant convergence or divergence between Adria and Africa between the end of spreading $(220 \mathrm{Ma})$ and the Neogene (20 Ma). We note that Tugend et al. (2019) recently suggested a Jurassic phase of opening for the Ionian Basin, which will be discussed in Sect. 5.2.

The motion of the Corsica-Sardinia Block (CSB) in Oligo-Miocene times is associated with the opening of the Liguro-Provençal Basin during the fast retreat of the Apennine subduction zone (e.g., Faccenna et al., 2001). Syn-rift and post-rift sediments along the Gulf of Lion date the onset of rifting to about $35 \mathrm{Ma}$ and the end of rifting to about $21 \mathrm{Ma}$ (Séranne, 1999; Jolivet et al., 2015). Paleomagnetic data indicate a clear rotation of Sardinia between 21 and $16 \mathrm{Ma}$ (Speranza et al., 2002; Gattacceca et al., 2007), which is interpreted as spreading along the Liguro-Provençal Basin. We reconstructed the motion of Corsica relative to France back to $35 \mathrm{Ma}$ using the amount of extension along the LiguroProvençal Basin estimated at ca. $115 \mathrm{~km}$ (ca. $60 \mathrm{~km}$ rifting and $55 \mathrm{~km}$ spreading; Le Breton et al., 2017). This fits very well with the rotation pole and amount of rotation proposed by Speranza et al. (2002) for Sardinia based on paleomagnetic data (Table 1).

The pre-Oligocene evolution of the CSB and its position with respect to Iberia is debated, as mentioned in Sect. 3.2. Here we follow the kinematic model where the CSB was part of Iberia and moved to its present-day location during a sinistral, transtensional motion of Iberia and the opening of the Valais Basin in Early Cretaceous times (Fig. 3, 1.B; e.g., Stampfli and Borel, 2002; Handy et al., 2010). Indeed, the Oligo-Miocene rotation of the CSB during the opening of the Liguro-Provençal Basin implies the presence of a transform fault between Iberia and Sardinia, the North Balearic Transform zone (NBTZ; e.g., van Hinsbergen et al., 2014), but there is no evidence for any shortening between eastern Spain and Sardinia. Thus, our approach is to avoid significant divergence-convergence between Iberia and the CSB and therefore to move them together relative to Europe prior to $35 \mathrm{Ma}$. We implement a strike-slip motion between Iberia and the CSB along the NBTZ to accommodate extension during the opening of the Pyrenean Rift system-Valais Basin in Mesozoic times (Table 1) and convergence in the PyreneesProvence belt (ca. $155 \mathrm{~km}$ between Sardinia and Provence; Bestani et al., 2016). This independent motion may explain, at least in part, the different rotation of the CSB compared to Iberia indicated by paleomagnetic studies (Advokaat et al., 2014) without having a significant paleogeographic separation between the two domains.

Moving the CSB with Iberia back in Mesozoic times is also in agreement with Carboniferous-Permian paleoreconstructions of Tuscany, Calabria, and Corsica that indicate a paleogeographic continuity between these three domains (Molli et al., 2020) and with paleo-reconstructions of the Western Alps that indicate a paleogeographic separation between the external crystalline massifs (Helvetic Zone, Europe) and the Briançonnais Zone (different pre-Triassic basement; Ballèvre et al., 2018). This in turn implies significant strike-slip motion (max. 700 km; Fig. 3, 1.B) between Europe and Iberia-CSB-Briançonnais along the North Pyrenean Fault and the East Variscan Shear zone, a Variscan transcurrent shear zone that was reactivated in Mesozoic times to accommodate the motion of Iberia relative to Europe during the opening of the North Atlantic, as proposed by previous authors (Choukroune, 1992; Matte, 2001; Stampfli and Borel, 2002; Sibuet et al., 2004; Guillot and Ménot, 2009; Guillot et al., 2009; Ballèvre et al., 2018). It also implies significant strike-slip motion (ca. $230 \mathrm{~km}$ ) within the Adriatic Plate to avoid an overlap between Corsica and northern Adria back to Triassic times (200 Ma; Fig. 3-2). This overlap or "Adria Problem" has already been mentioned by Wortmann et al. (2001), Stampfli and Borel (2002) and Schettino and Turco (2011) and implemented in Hosseinpour et al.'s (2016) kinematic model (based on rotation poles from Schettino and Turco, 2011; Table 1), in which they subdivided the Adriatic Plate into two plates - northern Adria and southern Adria (or Apulia) - along the Mattinata Fault (MF; 
Table 1. Total reconstruction rotations used in this study for Sardinia-Corsica and Adria.

\begin{tabular}{|c|c|c|c|c|c|}
\hline Age (Ma) & Latitude & Longitude & Angle & Moving vs. relative plate & Reference \\
\hline \multicolumn{6}{|c|}{ Corsica-Sardinia } \\
\hline 0.0 & 0.0 & 0.0 & 0.0 & COR-SAR vs. Europe & \\
\hline 16.0 & 0.0 & 0.0 & 0.0 & COR-SAR vs. Europe & Speranza et al. (2002) \\
\hline 21.0 & 43.5 & 9.0 & -23.0 & COR-SAR vs. Europe & Speranza et al. (2002) \\
\hline 35.0 & 43.5 & 9.0 & -53.2 & COR-SAR vs. Europe & This study (rifting Liguro-Provençal Basin) \\
\hline 83.0 & 42.7458 & 8.0933 & -56.8041 & COR-SAR vs. Europe & This study (shortening Provence) \\
\hline 83.0 & -44.7583 & -168.868 & 47.0239 & COR-SAR vs. Iberia & Crossover (change in relative plate) \\
\hline 93.0 & -44.4487 & -168.6366 & 47.77 & COR-SAR vs. Iberia & This study (end opening Valais Basin) \\
\hline 144.7 & -45.5809 & -166.3455 & 42.7547 & COR-SAR vs. Iberia & This study (opening Valais Basin) \\
\hline 250.0 & -45.5809 & -166.3455 & 42.7547 & COR-SAR vs. Iberia & \\
\hline \multicolumn{6}{|c|}{ Northern Adriatic Plate (Adria) } \\
\hline 0.0 & 0.0 & 0.0 & 0.0 & Adria vs. Apulia & \\
\hline 40.1 & 0.0 & 0.0 & 0.0 & Adria vs. Apulia & Schettino and Turco (2011) \\
\hline 47.0 & -26.5 & -166.58 & 1.0 & Adria vs. Apulia & Schettino and Turco (2011) \\
\hline 60.0 & -26.5 & -166.58 & 1.0 & Adria vs. Apulia & Schettino and Turco (2011) \\
\hline 70.0 & -26.5 & -166.58 & 2.0 & Adria vs. Apulia & Schettino and Turco (2011) \\
\hline 100.0 & -26.5 & -166.58 & 7.73 & Adria vs. Apulia & Schettino and Turco (2011) \\
\hline 250.0 & -26.5 & -166.58 & 7.73 & Adria vs. Apulia & Schettino and Turco (2011) \\
\hline \multicolumn{6}{|c|}{ Southern Adriatic Plate (Apulia) } \\
\hline 0.0 & 0.0 & 0.0 & 0.0 & Apulia vs. Europe & \\
\hline 20.0 & 38.2028 & -3.1628 & -5.3474 & Apulia vs. Europe & Le Breton et al. (2017) \\
\hline 20.0 & 50.5636 & 21.1076 & -2.9022 & Apulia vs. Africa & Crossover (change in relative plate) \\
\hline 220.0 & 50.5636 & 21.1076 & -2.9022 & Apulia vs. Africa & Africa moving with Africa \\
\hline 220.0 & 49.4645 & -0.0993 & -68.068 & Apulia vs. Europe & Crossover (change in relative plate) \\
\hline 230.0 & 50.4113 & -1.4579 & -68.534 & Apulia vs. Europe & This study (opening Ionian Basin, timing from \\
\hline 250.0 & 50.4113 & -1.4579 & -68.534 & Apulia vs. Europe & Speranza et al., 2012 \\
\hline
\end{tabular}

Figs. 1 and 3, 2B) across the Gargano Promontory. Multichannel seismic profiles along the eastward offshore continuation of this fault show evidence for strike-slip activity during the Late Cretaceous to Paleogene (Argnani et al., 2009). The amount of displacement (ca. $230 \mathrm{~km}$ ) is however most likely overestimated in our model. More tectonic deformations are observed within the Adriatic Sea to the north, along the so-called Mid-Adriatic Ridge (Scisciani and Calamita, 2009; previously named Central Adriatic Deformation belt by Argnani and Frugoni, 1997). This ridge was formed by transpressional reactivation of pre-existing rift-related Mesozoic structures, mostly in Plio-Pleistocene times as shown along seismic profile CROP M15 and present-day GPS data (D'Agostino et al., 2008). An earlier inversion phase is observed by lateral thickness variations and unconformities above the Albian-Aptian reflector (see Fig. 6 of Scisciani and Calamita, 2009), especially during the Paleogene-Miocene succession (Figs. 3 and 8 of Scisciani and Calamita, 2009). Moreover, strike-slip deformation and reactivation of Jurassic rift-related structures in Cretaceous-Eocene times have been reported from the Southern Alps (Castellarin et al., 2006) to the Central Apennines (Cipriani and Bottini, 2019a, b). It is thus very likely that the entire Adriatic Plate actually deformed in a more diffuse way along a series of strike-slip faults in Late Cretaceous-Paleogene times. However, it is extremely challenging to constrain the exact magnitude and timing of motion along those faults and would require further investigations in the future. For the sake of simplicity, we follow the model of Schettino and Turco (2011) and Hosseinpour et al. (2016) and divide the Adriatic Plate into two plates along a single major strike-slip fault. Our model can thus be viewed as an end-member model that implies a maximum amount of sinistral strike-slip displacement along the Mattinata Fault and between Europe and Iberia-CSB but best fits the paleogeography of Adria-Sardinia-Calabria (Molli et al., 2020) and the subduction record of the PL Basin (Sect. 2). Sinistral motion along the Mattinata Fault (ca. $230 \mathrm{~km}$ ) to "restore" Adria to its present-day configuration is accommodated progressively during the counterclockwise motion of Africa relative to Europe, between ca. 100-40 Ma. Thus, it does not affect the opening kinematics of the PL Basin occurring earlier in the Jurassic (Sect. 2), which is the focus of this paper. The implication of this strike-slip motion within 
Adria is discussed in Sect. 5.3 in terms of plate convergence during the Alpine Orogeny.

\subsection{Reconstruction of the AlKaPeCa units}

West of Adria, remnants of the Western Mediterranean subduction zone are found today in southern Spain (Alboran), northern Africa (Kabylia), Sicily (Peloritani), and southern Italy (Calabria; Fig. 1), together referred to as the AlKaPeCa units (Bouillin et al., 1986; Guerrera et al., 1993; Michard et al., 2002, 2006). These units are continentally derived, far-traveled nappes that acquired their present-day position during the fast rollback of the Gibraltar and Calabrian subduction zones in Oligo-Miocene times. For this time period, we used the tectonic reconstructions of Van Hinsbergen et al. (2014), which are based on a compilation of shortening and extension estimates from the Atlas Mountains, the Betic Cordillera, the Alboran domain, the Algerian Basin, the Gulf of Valencia, and the Tyrrhenian Sea (Fig. 1).

The similarity of the Triassic-Liassic stratigraphy and the Variscan basement between the $\mathrm{AlKaPeCa}$ units and coeval Tuscan and Sesia domains on the Adriatic Plate suggest that the $\mathrm{AlKaPeCa}$ units were originally derived from a microplate that rifted away from the Iberian-CSB-AfricaAdria continental margins during the opening of the PL Basin in Jurassic times (Michard et al., 2002, 2006; Molli, 2008; Molli et al., 2020). Similar "Adria-like" features are found in Corsica within the Nebbio units (Molli, 2008), which also suggests a possible continuity of this continental microplate to the northeast, between Corsica and Adria towards Sesia (Michard et al., 2002, 2006), and thus supports our reconstructions of the CSB (Sect. 3.3). This microplate has various names in the literature (e.g., "Alcapecia" in Handy et al., 2010; "Mesomediterranean terrane" in Guerrera et al., 2019). To simplify, we refer only to "AlKaPeCa" here and want to point out that the exact extent of this microplate in Mesozoic times is very uncertain (hence the question marks on our tectonic maps; Fig. 4). This microplate is important for the geodynamic evolution of this region as it separated a northern and a southern branch of the PL Ocean, supported by the presence of Tethys-derived ophiolite units in the Betic Cordillera (southern Spain) and in the Maghrebide Belt (northern Africa-Sicily), respectively (Michard et al., 2002, 2014; Guerrera et al., 2019). The polarity of subduction zone(s) in this area is debated (e.g., Jolivet et al., 1998; Argnani, 2012; Guerrera et al., 2019). In our tectonic reconstructions, we follow a "two-subduction" model that implies first a southeast-dipping (Alpine) subduction of the northern branch of the PL Ocean in Late Cretaceous-Eocene times followed by a switch of subduction polarity to westnorthwest (Apennine) subduction of the southern branch of the PL Ocean when the microplate entered the subduction zone at $~ 35$ Ma (e.g., Michard et al., 2006; Molli, 2008; Molli and Malavieille, 2011).

\subsection{Reconstruction of the AlCaPa-Tisza-Dacia units}

Other tectonically complex and far-traveled nappes are found east of Adria in the Eastern Alps, Carpathians, and beneath the Pannonian Basin: the AlCaPa-Tisza-Dacia units. The $\mathrm{AlCaPa}$ (Alps-Carpathians-Pannonian) unit is derived from Adria and corresponds to the Austroalpine nappes of the Eastern Alps and the Inner West Carpathians (Schmid et al., 2008; Fig. 1). The Tisza and Dacia units, presently beneath the Pannonian Basin, consist of tectonic units with a mixed European and Adriatic affinities (Schmid et al., 2008; Handy et al., 2015). These three tectonic units comprise a long and complex tectonic evolution from the opening and closure of several oceans (Neo-Tethys and part of Alpine Tethys; e.g., Schmid et al., 2008, 2020). During the Neogene, they underwent significant extension and rotation during the fast rollback of the Carpathian subduction zone and upper-plate extension with the opening of the Pannonian Basin (e.g., Ustaszewski et al., 2008, and references therein). Thus, it is extremely challenging to reconstruct their past position and former extent. For the Jurassic, we follow Schmid et al. (2008) and Vissers et al. (2013), who proposed that TiszaDacia separated from Europe during the opening of the eastern part of the PL Ocean. This in turn implies a strike-slip motion along the Dobrogea Fault zone northeast of Moesia, which remains poorly constrained (question marks in Fig. 4). After the opening of the PL Ocean, convergence between Africa and Europe was accommodated within the $\mathrm{AlCaPa}$ unit along an intracontinental subduction zone (Eo-Alpine orogen; Stüwe and Schuster, 2010). The accretion of the Austroalpine nappes was complete by ca. $84 \mathrm{Ma}$, and the Alpine south-dipping subduction of Alpine Tethys initiated (Handy et al., 2010). For the Late Cretaceous-Cenozoic, our model is based on the tectonic reconstructions of Handy et al. (2015) and Ustaszewski et al. (2008). This area remains extremely simplified in our tectonic maps (Fig. 4) as this is beyond the scope of our study; a more detailed review and reconstruction of this area can be found in Schmid et al. (2020) and van Hinsbergen et al. (2020).

\section{Results}

\subsection{Tectonic maps back to $200 \mathrm{Ma}$}

Following the geological records and kinematic constraints summarized in the past two sections, we constructed a series of tectonic maps of the Alpine-Mediterranean area (Fig. 4) for key times covering the opening of the Piemont-Liguria Ocean (200-130 Ma) and the Alpine Orogeny (83-0 Ma). These maps are a deliberately simplified representation and aim to show the main plates and plate boundaries through time. They do not show intraplate deformation nor rifting along the continental margins. Those regional reconstructions are incorporated into the global plate model of Müller et 


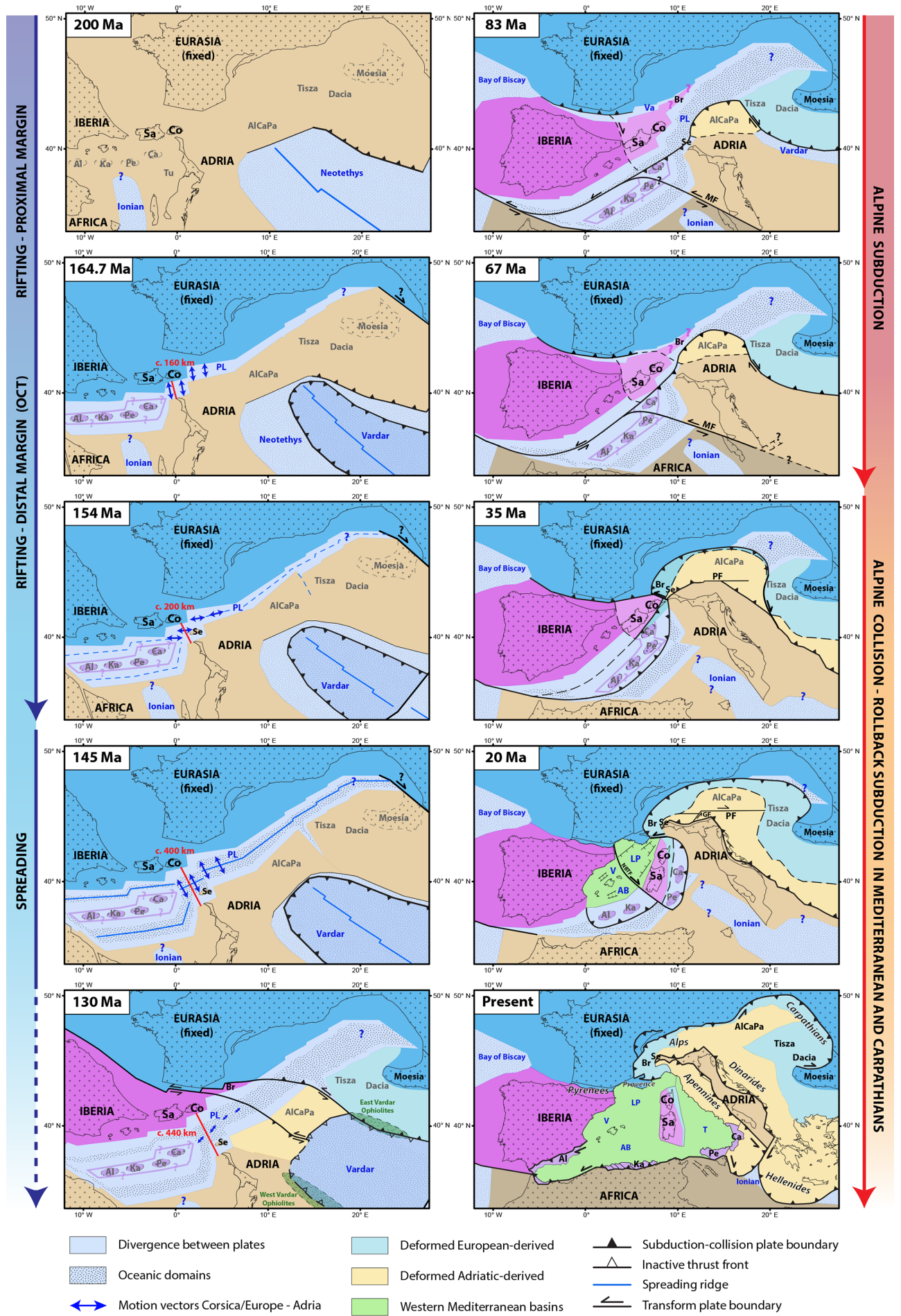

Figure 4. Simplified tectonic maps of the Western Mediterranean-Alpine area from 200 to $130 \mathrm{Ma}$ (divergent phase - left panels) and from 83 to $0 \mathrm{Ma}$ (convergent phase - right panels), relative to Eurasia (fixed), showing the main plate boundaries and divergence between EuropeCorsica and Adria (blue vectors). The amount of divergence along a 2D transect between Corsica and Adria is indicated in red. Note that these maps do not show intraplate deformation and rifting along the continental margins but the divergence between plates when considered rigid. This study focuses on the area between Corsica-Europe and Adria, as the exact paleo-location of the AlKaPeCa units to the west and AlCaPa-Tisza-Dacia units to the east is poorly constrained. Present-day coastlines are represented for orientation. Abbreviations: AB - Algerian Basin; Al - Alboran; AlCaPa - Alpine-Carpathians-Pannonian unit; Br - Briançonnais; Ca - Calabria; Co - Corsica; GF Giudicarie Fault; Ka - Kabylides; LP - Liguro-Provençal Basin; NBTZ - North Balearic Transform zone; Pe - Peloritani; PF - Periadriatic Fault; PL - Piemont-Liguria (Basin and Ocean); Sa - Sardinia; SCRZ - Sicily Channel rift zone; Se - Sesia; Tu - Tuscany; T - Tyrrhenian Sea; V - Gulf of Valencia; Va - Valais Basin. 
al. (2019). Animations showing the evolution of the AlpineMediterranean back to $250 \mathrm{Ma}$ and age grids of the PL Ocean are available at https://www.earthbyte.org/webdav/ ftp/Data_Collections/Muller_etal_2019_Tectonics/ (last access: 12 April 2021).

The divergent motion between the two major plates $-\mathrm{Eu}-$ rope vs. Africa (Adria) - in the Jurassic (blue vectors in Fig. 4, obtained with the "flowline" tool on GPlates) shows different stages of the opening of the PL Basin: first, a NNWSSE-directed (relative to Europe, fixed) divergence between 200 and 164.7 Ma (Early-Middle Jurassic), followed by an oblique E-W-directed motion until 154 Ma (Middle-Late Jurassic). Then the main divergent phase occurs between 154 and $145 \mathrm{Ma}$ (Late Jurassic) in a NW-SE direction. At $145 \mathrm{Ma}$ (Early Cretaceous), Iberia and CSB start moving relative to Europe due to the opening of the North Atlantic. This oblique motion significantly decreases the divergence in the PL Basin, which ends entirely at about $130 \mathrm{Ma}$. The different stages of the opening of the PL Basin (200, 164.7, 154, 145, and $130 \mathrm{Ma}$ ) are derived from the stages of the opening of the central Atlantic (Kneller et al., 2012) and the North Atlantic (Barnett-Moore et al., 2018).

Based on the review of geological events given in Sects. 2 and 3, we can summarize the main stages of convergence (right panels of Fig. 4) as follows. From $130 \mathrm{Ma}$, the motion between Europe, Iberia, and Africa (Adria) is mostly strikeslip. Subduction of parts of the PL Ocean to the east starts in response to the eastward motion of Iberia-CSB and is kinematically linked with the Eo-Alpine Orogeny within the Al$\mathrm{CaPa}$ unit. At $83 \mathrm{Ma}$, the oblique motion of Iberia and Africa relative to Europe becomes more orthogonal. The Alpine south-directed subduction starts, with Adria and the accreted $\mathrm{AlCaPa}$ unit as part of the upper plate. The subduction progresses from southeast to northwest, with the progressive subduction of Sesia, the PL Ocean, the Briançonnais, the Valais Basin, and finally the European margin. At $35 \mathrm{Ma}$, collision starts in the Alps while subduction continues more to the east along the Carpathians and switches to the Apennine northwest-directed subduction in the Western Mediterranean. Finally, from 35-20 Ma onwards, fast rollback of the Gibraltar and Calabria subduction zones in the Western Mediterranean, of the Hellenic subduction in the Eastern Mediterranean, and of the Carpathians is accompanied by the indentation of the Adriatic Plate into Europe, lateral extrusion of the Eastern Alps towards the east, and upper-plate extension and the opening of the Pannonian Basin, the Western Mediterranean basins, and the Aegean Sea, shaping the complex arcuate and broadly deformed plate boundaries that we can observe today.

\subsection{Velocities of rifting and spreading along the $P L$ Basin}

We estimate the velocities of plate divergence during the opening of the PL Basin (Fig. 5) using the motion vec- tors between Europe (Corsica-Briançonnais) and Adria (blue vectors in Fig. 4). Full rates of opening are first very slow (ca. $4 \mathrm{~mm} \mathrm{yr}^{-1}$ from southwest to northeast) between 200 164.7 Ma. They accelerate first to ca. $15 \mathrm{mmyr}^{-1}$ (16 to $14 \mathrm{~mm} \mathrm{yr}^{-1}$ from southwest to northeast) between 164.7$154 \mathrm{Ma}$ and then to ca. $22 \mathrm{mmyr}^{-1}$ (ranging from 24 to $21 \mathrm{~mm} \mathrm{yr}^{-1}$ from southwest to northeast) between 154$145 \mathrm{Ma}$. They decrease significantly at $145 \mathrm{Ma}$ down to ca. $5 \mathrm{~mm} \mathrm{yr}^{-1}$ until $130 \mathrm{Ma}$. We assess an uncertainty of $\pm 5 \mathrm{~km}$ in measuring the vector length, which - once divided by the shortest time period (154-145 Ma) - leads to an error bar of up to $\pm 0.5 \mathrm{~mm} \mathrm{yr}^{-1}$ in the calculated rates. The slight increase in rate from southwest (Corsica-Adria) to northeast (Briançonnais-Adria) indicates a triangular-shape opening of the PL Basin.

The first slow phase (ca. $4 \mathrm{mmyr}^{-1}$ ) coincides in time with the opening of the central Atlantic (Kneller et al., 2012) and the tectono-stratigraphic record of rifting along the PL Basin (Fig. 5; Sect. 2.1.1; e.g., Froitzheim and Eberli, 1990). The first acceleration at ca. $165 \mathrm{Ma}$ fits in with an increase in spreading rate in the central Atlantic (from ultra-slow to slow; Kneller et al., 2012) and the onset of deep-sea sedimentation, mantle exhumation, and MORB-type magmatism in the PL Basin (Fig. 5; Sect. 2.1.1; e.g., Bill et al., 2001; Manatschal and Müntener, 2009). The fastest rates of divergence are found in a very short time period of 9 Myr (154-145 Ma) and are in the range of a slow to ultra-slow-spreading ridge $\left(<20 \mathrm{~mm} \mathrm{yr}^{-1}\right.$; Dick et al., 2003). The drop at $145 \mathrm{Ma}$ coincides with a decrease in spreading rates in the central Atlantic (Kneller et al., 2012) and the opening of the North Atlantic (Barnett-Moore et al., 2018).

\subsection{Thinning of the continental margins}

The total amount of divergence along a NW-SE-directed transect between Corsica and northern Adria (in red in Fig. 4) equals ca. $440 \mathrm{~km}$ and can be subdivided into $160 \mathrm{~km}$ between 200-164.7 Ma, $40 \mathrm{~km}$ between 164.7-154 Ma, $200 \mathrm{~km}$ between $154-145 \mathrm{Ma}$, and $40 \mathrm{~km}$ between $145-130 \mathrm{Ma}$. However, this does not represent the actual width of the basin but the amount of total horizontal divergence (elongation). To estimate the final length of the rifted margins and ocean, we use a simple "pure-shear" (symmetric and uniform) stretching approach (McKenzie, 1978) for which we need to assume the initial length of area affected by rifting. Here we presume an initial length of ca. $300 \mathrm{~km}$, obtained from restoring the length of the base of syn-rift horizons across the present-day Southern Alps and Adriatic Foreland affected by rifting in the Jurassic (Masetti et al., 2012) and facing "stable" (i.e., not affected by rifting) Corsica in our reconstructions back to $200 \mathrm{Ma}$ (Fig. 6). This amount should be regarded as an absolute minimum, as this section represents only the preserved proximal part of the Adriatic margin. The present-day W-E orientation of the rift basins becomes NNW-SSE relative to Europe once back-rotated with Adria 


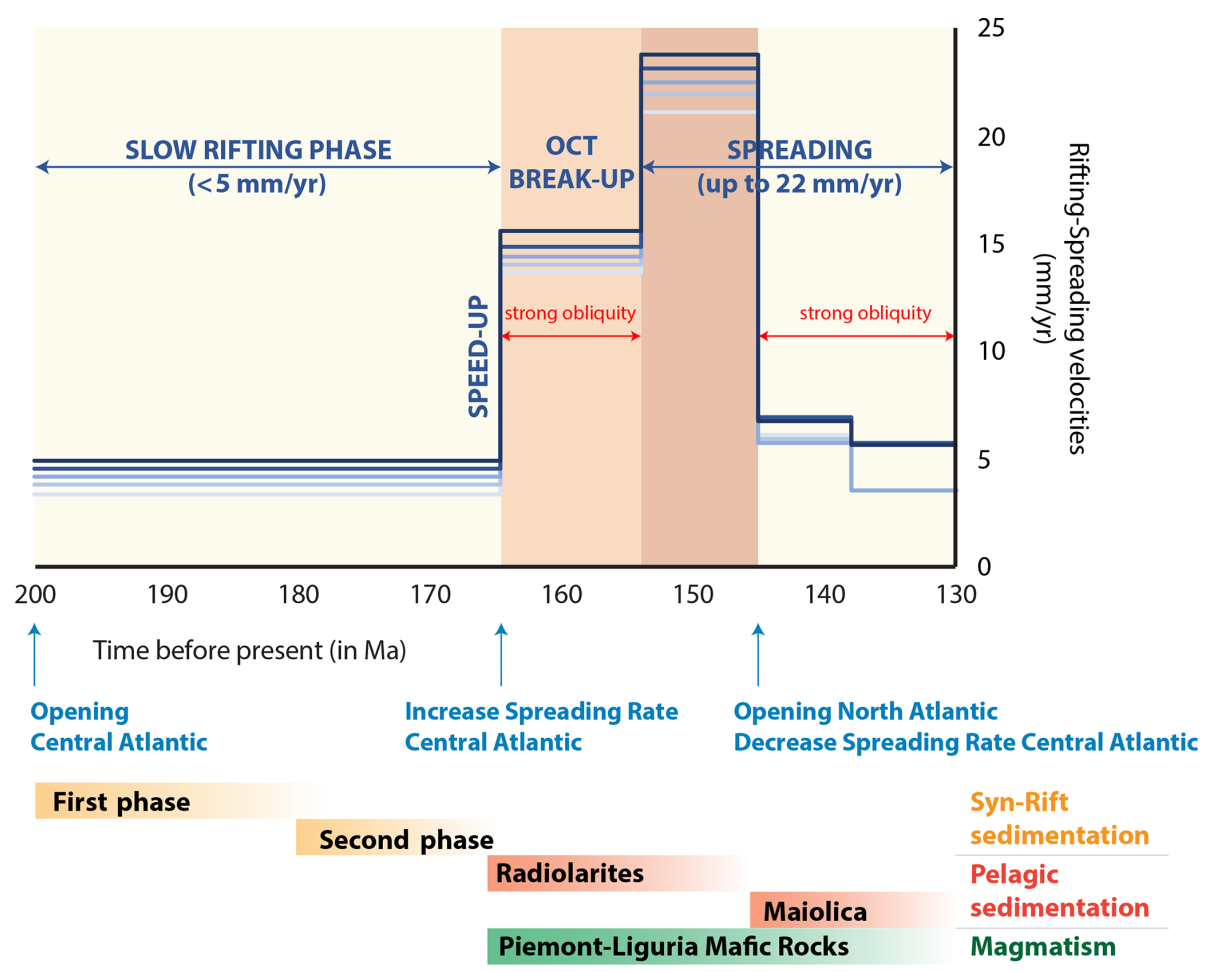

Figure 5. Velocities (full rate) of rifting and spreading along the PL Basin between Europe (Corsica-Briançonnais) and Adria (blue vectors in Fig. 4) in Jurassic to Early Cretaceous times. Timing of syn-rift sedimentation from Froitzheim and Eberli (1990), deep-sea pelagic sedimentation from Bill et al. (2001) and Ferrando et al. (2004), and U-Pb ages on zircons from mafic rocks of the PL Ocean from Manatschal and Müntener (2009, and references therein). Note the slight increase in velocities from northeast to southwest (light to dark blue curves) and the strong acceleration at 164.7 and $154 \mathrm{Ma}$ for all curves.

at $200 \mathrm{Ma}$ (Fig. 6), which fits in well with the kinematics of the opening of the PL Basin obtained from our reconstructions (Fig. 4; Sect. 4.1). Assuming an initial crustal thickness of $30 \mathrm{~km}$ (Masini et al., 2013) and a localization of the rift after the slow rifting phase described above (200-165 Ma) along a zone of $80 \mathrm{~km}$ (typical for narrow rifts such as the East African Rift today; Ebinger et al., 1999; Corti, 2009; Brune et al., 2017a), we estimate a total length of $380 \mathrm{~km}$ for the proximal margins ( $>10 \mathrm{~km}$ thick), $120 \mathrm{~km}$ for the hyper-extended or OCT zone ( $<10 \mathrm{~km}$ thick), and $240 \mathrm{~km}$ of oceanic crust (Fig. 6). This remains a simple approximation as it does not take into account asymmetry during rifting, necking, and hyper-extension but nevertheless provides a first-order estimate.

\subsection{Geodynamic consistency}

In order to test our kinematic model in the context of rifting and thinning of the PL Basin in more detail, we use a 2D thermo-mechanical modeling approach that is based on the geodynamic finite-element software SLIM3D (Popov and Sobolev, 2008). This model is driven solely by boundary velocities while the localization of rift faults, lithospheric necking, continental breakup, and subsequent seafloor spreading evolves in a purely self-consistent manner. The model in- volves four layers (upper crust, lower crust, strong and weak mantle), which all deform in accordance with corresponding flow laws (wet quartzite, wet anorthite, dry olivine, and wet olivine, respectively). The initial Moho depth is set to $33 \mathrm{~km}$ and the lithosphere-asthenosphere boundary (LAB, $1300^{\circ} \mathrm{C}$ ) to $120 \mathrm{~km}$. The LAB is slightly elevated $(5 \mathrm{~km})$ in the center of the model to avoid rift localization at the model boundaries (Fig. 7a). We follow a model setup that has been extensively used in modeling narrow rifting and rifted margin formation (Brune et al., 2012, 2013, 2017a, b; Brune, 2014), and for a more detailed description of the employed boundary conditions, initial conditions, weakening mechanisms, and material parameters, we refer the reader to Brune et al. (2014).

It is well-established that the rift velocity exerts a key control on the structural evolution of a rift (Huismans and Beaumont, 2003; Pérez-Gussinyé et al., 2006; Tetreault and Buiter, 2018). In order to test the impact of our kinematic plate tectonic model, we derive rift-perpendicular velocities from the 2D transect between Corsica-Adria (red transect in Fig. 4) as input for the geodynamic modeling by means of the following steps: (1) $4 \mathrm{~mm} \mathrm{yr}^{-1}$ for the first $46 \mathrm{Myr}$ (200 km divergence between 200-154 Ma); (2) $22 \mathrm{~mm} \mathrm{yr}^{-1}$ for $9 \mathrm{Myr}(200 \mathrm{~km}$ divergence between $154-145 \mathrm{Ma})$, and (3) $3 \mathrm{~mm} \mathrm{yr}^{-1}$ for $15 \mathrm{Myr}$ (40 km divergence between 145- 


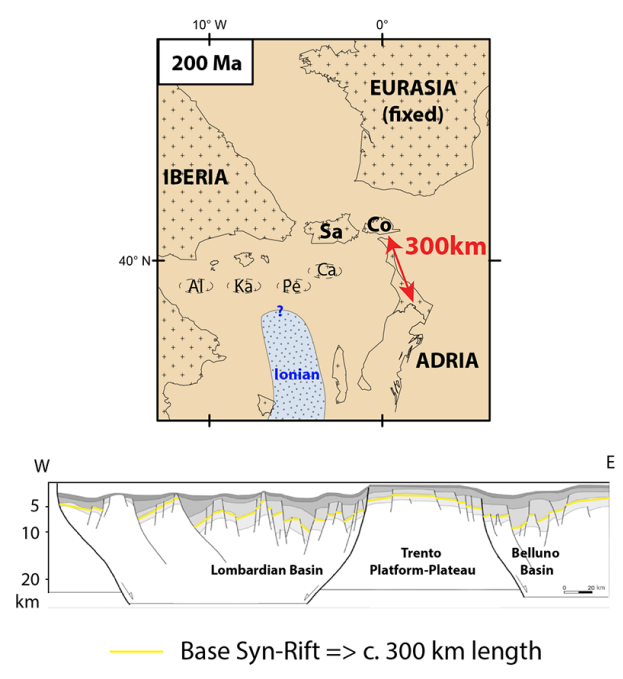

$200 \mathrm{Ma}$
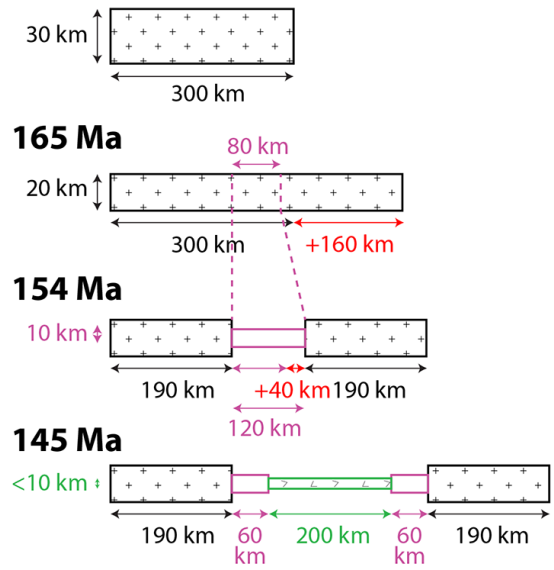

$130 \mathrm{Ma}$

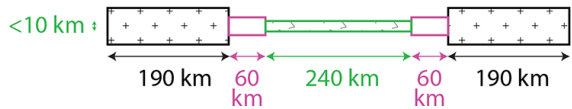

\section{Rifting}

Elongation of $160 \mathrm{~km}$ Thinning of $10 \mathrm{~km}(2 / 3)$

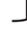

\section{Hyper-extension OCT formation \\ Elongation of $40 \mathrm{~km}$ \\ Thinning of $10 \mathrm{~km}(1 / 2)$}

\section{Ultra-Slow Spreading}

Elongation of $200 \mathrm{~km}$

Break-up of continental crust

\section{End of Spreading}

Elongation of $40 \mathrm{~km}$

Figure 6. Thinning of continental crust and extent of rifted margins along a 2D transect from Europe (Corsica) and Adria using amount of divergence (elongation) from kinematic reconstructions (red transect in Fig. 4) and a pure-shear approach (McKenzie, 1978). The initial length of $300 \mathrm{~km}$ is assumed by restoring the length of the base of syn-rift horizons along the Southern Alps and Adriatic Foreland (lower left, redrawn from Masetti et al. (2012). Note that the present-day W-E orientation becomes NNW-SSE relative to Europe once back-rotated with Adria at $200 \mathrm{Ma}$ as shown on our tectonic map (upper left, red arrow).

$130 \mathrm{Ma})$. We point out that the first acceleration shown in Fig. 5 (15 $\mathrm{mm} \mathrm{yr}^{-1}$ between ca. $\left.165-154 \mathrm{Ma}\right)$ is obtained from the plate motion vectors (blue vectors in Fig. 4) and reflects the strong obliquity of motion during that phase; however, along a 2D transect the net divergence is only $40 \mathrm{~km}$ between $164.7-154 \mathrm{Ma}\left(3.6 \mathrm{mmyr}^{-1}\right)$. Thus, this phase is accounted for in the first step of our model (with rates of $4 \mathrm{~mm} \mathrm{yr}^{-1}$ ).

The modeling results are available as an animation in the Supplement (movie S1). The results after 1 (model setup), 20, 35, 46, 55, and $70 \mathrm{Myr}$ are shown in Fig. 7 and allow us to distinguish between different rifting stages (Fig. 7a-d, constant velocity of $4 \mathrm{~mm} \mathrm{yr}^{-1}$ ). First, the entire domain is affected by normal faults (Fig. 7a) until lithospheric necking commences at about $12 \mathrm{Myr}$ into the model runtime. The rift localizes along a zone of about $110 \mathrm{~km}$ width and the onset of hyper-extension $(<10 \mathrm{~km}$ crustal thickness; Lavier and Manatschal, 2006) starts after $20 \mathrm{Myr}$ (Fig. 7b). The onset of mantle exhumation occurs after $35 \mathrm{Myr}$ (Fig. 7c) and is accompanied by the detachment of continental allochthons. Finally, the continental lithosphere breaks up rapidly when the rift velocity increases to $22 \mathrm{~mm} \mathrm{yr}^{-1}$ at $46 \mathrm{Myr}$ (Fig. 7d). This is the moment when the lithosphere shallows drastically $(<10 \mathrm{~km}$; Fig. $7 \mathrm{~d}$; movie S1), as observed beneath present-day ultra-slow-spreading ridges (e.g., Mohns Ridge; Johansen et al., 2019), which would lead to decompression melting and the onset of seafloor spreading.

\section{Discussion}

\subsection{Opening and extent of the PL Basin}

Using our kinematic reconstructions and geodynamic modeling of the rifting phase, we can identify and date the following four stages of the opening of the PL Basin (Figs. 5-7), as defined by Lavier and Manatschal (2006):

1. "Stretching Phase" - rifting of the proximal continental margin and necking of the lithosphere between 200$180 \mathrm{Ma}$ (first rifting phase);

2. "Thinning Phase" - hyper-extension of the distal continental margin between 180-165 Ma (second rifting phase);

3. "Exhumation Phase" - OCT formation with mantle exhumation between $165-154 \mathrm{Ma}$;

4. "Spreading Phase" - breakup and slow to ultra-slow oceanic spreading between mostly 154-145 Ma.

Our results fit in very well with independent datasets (tectono-sedimentary, geochemical, geochronological) from the Alps (Sect. 2.1.1; Fig. 5) that show two rifting phases (ca. 200-180, 180-165 Ma; e.g., Froitzheim and Eberli, 1990; Mohn et al., 2010; Ribes et al., 2019), activation of the necking zone around $180 \mathrm{Ma}$ (Mohn et al., 2012; Ribes et al., 2019), and the onset of mantle exhumation and magmatism along typical magma-poor OCT at about $165 \mathrm{Ma}$ (e.g., Manatschal and Müntener, 2009; Ribes et al., 2019). 


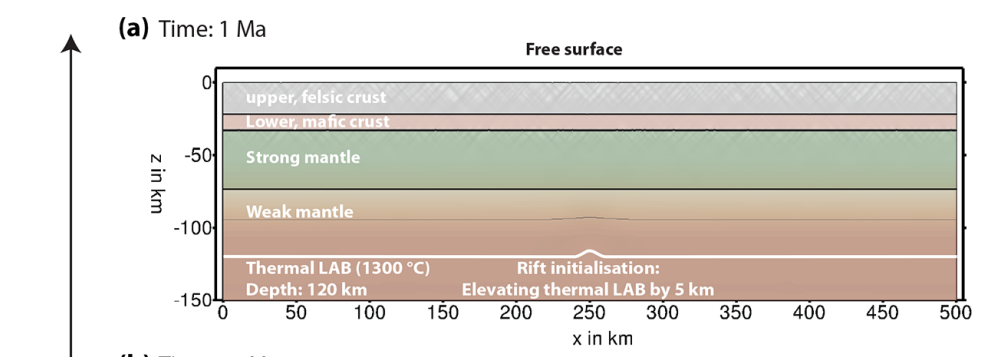

(b) Time: $20 \mathrm{Ma}$

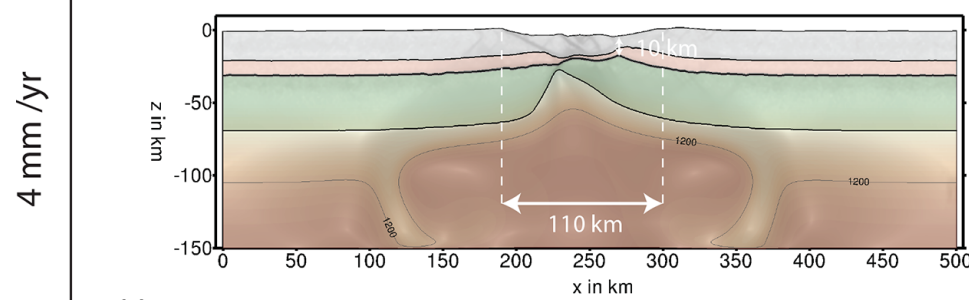

(c) Time: $35 \mathrm{Ma}$

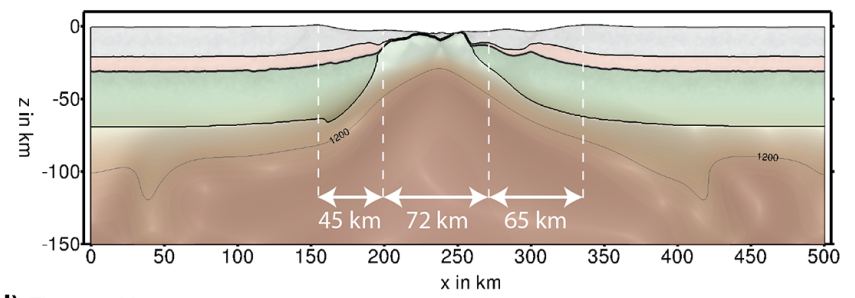

(d) Time: $47 \mathrm{Ma}$

(e) Time: $55 \mathrm{Ma}$
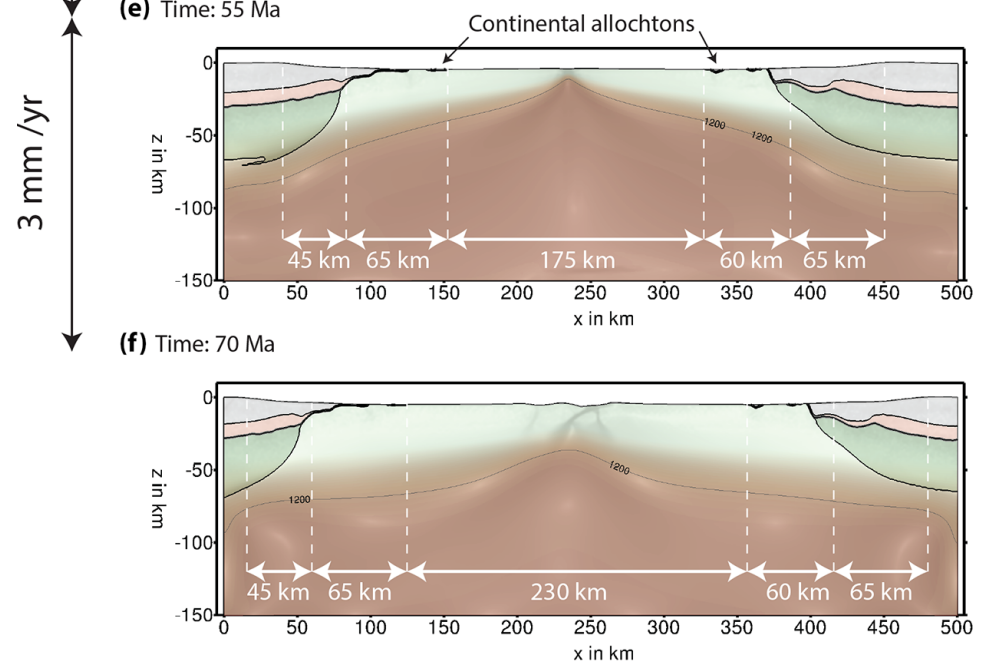

dII: $-18-17-16-15-14-13$

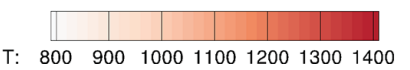

Initial stage: $33 \mathrm{~km}$ continental crust

200 - $180 \mathrm{Ma}$

Stretching phase

-> Proximal Domain

$180 \mathrm{Ma}$ : Onset of hyper-extension

(<10 km crustal thickness)

180 - $165 \mathrm{Ma}$

Thinning phase

-> Hyper-extended Domain

$165 \mathrm{Ma}$ : Onset of mantle exhumation

165 - $154 \mathrm{Ma}$

Exhumation phase

-> Ocean-Continent Transition

$154 \mathrm{Ma}$ : Breakup of continental lithosphere

154 - 145 Ma

Spreading phase $(22 \mathrm{~mm} / \mathrm{yr})$

-> Oceanic Lithosphere

145 Ma: Decrease spreading rates

145 - $130 \mathrm{Ma}$

Spreading phase ( $3 \mathrm{~mm} / \mathrm{yr}$ )

-> Oceanic Lithosphere

Figure 7. Two-dimensional high-resolution thermo-mechanical modeling of the opening of the PL Basin using velocities from our kinematic reconstructions (red transect between Europe and Adria in Fig. 4). Material phases are indicated in (a). Strain rate is visualized as black transparent overlay. Deep lithospheric and asthenospheric temperatures are depicted by brownish overlay and $1200^{\circ} \mathrm{C}$ isotherm (black line). Extent of necking zone (30-10 km thick), hyper-extended domain, and OCT ( $<10 \mathrm{~km}$ thick) and oceanic domain is indicated in white. See text for further discussion. Animation of model results can be found as movie S1 in the Supplement. 
Our kinematic reconstructions show an increase in obliquity and rate of plate motion between 165-154 Ma (Figs. 4 and 5) and a progressive opening of the PL Basin from southwest to northeast (Fig. 5). Thus the transition between stages 3 and 4, i.e., breakup and onset of spreading, was most likely a propagating process from southwest to northeast. Interestingly, abrupt plate acceleration such as the one at ca. $165 \mathrm{Ma}$ ("speed-up" in Fig. 5) is commonly observed along other continental margins worldwide (Brune et al., 2016). On other margins, this acceleration corresponds to the shaping of the distal part of the margins, pre-dating continental breakup of about 5-10 Ma, and reflects a strength-velocity feedback mechanism during rifting ("dynamic rift weakening"; Brune et al., 2016). Moreover, Brune et al. (2018) showed a clear correlation between rift obliquity and increase in plate motion velocities, as we observed between 165-154 Ma (Fig. 5). However, it is the effective rift-perpendicular velocity that leads to lithospheric thinning and thus oblique segments need more time to reach breakup than orthogonal rifts. This corroborates our interpretation that stage 3 (165-154 Ma) corresponds to the formation of the (hyper-)distal OCT zone, with the juxtaposition of pelagic sediments, serpentinized mantle, gabbros, and basalts (e.g., Epin et al., 2019) prior to breakup. The detachment of continental allochthons, such as Sesia (Fig. 4; e.g., Babist et al., 2006), also occurs during that stage, which fits in with the crystallization age (164$156 \mathrm{Ma})$ of zircons within syn-magmatic shear zones south of the Sesia zone (U-Pb zircon age; Kaczmarek et al., 2008). We therefore diverge from $\mathrm{Li}$ et al. (2013), who interpret this phase as oceanic spreading. We instead suggest that most of the preserved mafic rocks came from the OCT domain rather than the mature oceanic domain, mostly lost to subduction, which is supported by the subcontinental (refertilized) mantle-type composition of most peridotites of the ophiolites preserved in the Alps (Picazo et al., 2016). A subcontinental affinity of the exhumed mantle has been inferred from petrological analysis in the Western Alps suggesting diffuse porous flow of asthenospheric melts through the continental lithospheric mantle as a key process (Piccardo and Guarnieri, 2010). Similar to other recent modeling efforts (Hart et al., 2017; Andrés-Martínez et al., 2019; Jammes and Lavier, 2019), our numerical models do not capture porous flow processes and are therefore not comparable with this type of observation. However, they show that the asthenospheric mantle resided close to the continental mantle lithosphere prior to exhumation, which might be indicative of continental mantle affinity. Furthermore, our interpretation does not exclude the possibility that the first immature or embryonic oceanic domains, such as the ChenailletMontgenèvre ophiolite (oceanic mantle type, Picazo et al., 2016; U-Pb ages ranging from $148-156$ to $165 \mathrm{Ma}$; Costa and Caby, 2001; Li et al., 2013, respectively), formed already during this phase of very oblique plate motion. Still we propose that the formation of mature oceanic crust took place when the plate motion became more orthogonal and rates of opening reached ca. $22 \mathrm{~mm} \mathrm{yr}^{-1}$ (Figs. 4 and 5). Indeed, our modeling results show that mechanical breakup of the continental lithosphere coincides with the increase in riftperpendicular velocity (Fig. $7 \mathrm{~d} ; 1200^{\circ} \mathrm{C}$ at $10 \mathrm{~km}$ depth). We have to caution that the numerical model cannot clearly differentiate between mantle exhumation prior to breakup and potential mantle exhumation during spreading. In either case, mature oceanic spreading was slow to ultra-slow and very short-lived (9 Ma), as the divergence along the PL domain decreased significantly at $145 \mathrm{Ma}$ and completely ceased at $130 \mathrm{Ma}$.

Our geodynamic modeling, constrained by our plate reconstructions, reproduces the kinematics of the different rifting phases recorded in the Alps but also the first-order structures of the hyper-extended margins. The final "shape" of the distal rifted margin obtained from our modeling (Fig. 7e) agrees with geological reconstructions of the Alpine Tethys margins (Mohn et al., 2012, their Fig. 2). Moreover, we provide quantitative constraints on the final width of the different domains: (1) 45-65 km for the necking zone (thinning of the crust from 30 to $10 \mathrm{~km}$; Fig. 7); (2) 40-80 km for the distal margin (crust thinner than $10 \mathrm{~km}$, hyper-extended and OCT domains; Fig. 7); (3) maximum $250 \mathrm{~km}$ for the oceanic domain (Figs. 4, 6, and 7). Hence, the total width of the PL Basin, including both the rifted continental margins (thinner than $30 \mathrm{~km}$ ) and the oceanic crust featured a total extent of $480 \mathrm{~km}$ (Fig. 7e).

The kinematic evolution of the comparably small PL Basin is closely linked to the much larger neighboring Atlantic Ocean, and the variation in rifting or spreading velocities coincides with changes in divergence rates of the central Atlantic (Fig. 5). The PL Ocean opened as a third arm of the central Atlantic Ocean in Jurassic times (as previously proposed; e.g., Stampfli and Borel, 2002) and "died out" when the North Atlantic took over at ca. 145 Ma (Barnett-Moore et al., 2018). It then closed due to the opening of the South Atlantic (e.g., Müller et al., 1999) and the ensuing counterclockwise motion of Africa relative to Europe in CretaceousCenozoic times.

\subsection{Assessing the model}

The kinematics of the opening of the PL Basin are primarily governed by the motion of Europe and Adria, as IberiaSardinia-Corsica started to move at $145 \mathrm{Ma}$, i.e., after the opening of the PL Basin. In our model, it is more precisely governed by the motion of Europe and Africa since we assume Adria rigidly connected with Africa after the opening of the Ionian Basin in Triassic times and prior to the strikeslip motion along the MF in Cretaceous-Cenozoic times (see Sect. 3.3). Thus our results are extremely dependent on the kinematic reconstructions used for the opening of the central Atlantic in the Jurassic, in this case the model of Kneller et al. (2012). The latter is based on a non-rigid inversion method that restores incrementally crustal stretching allowing a bet- 
ter restoration of the syn-rift to breakup phase and producing realistic subsidence and crustal thinning patterns that are consistent with field observations. Other recently published models for the central Atlantic, such as Labails et al. (2010), however, show significant gaps in palinspastic restorations of the margins (see further discussion in Kneller et al., 2012). Moreover, when using the rotation poles of Labails et al. (2010) for the central Atlantic, we obtain a phase of convergence rather than divergence between 190 and $170 \mathrm{Ma}$ in the PL domain between Europe-Adria. This is in contradiction with the clear record of syn-rift basins of Early Jurassic age in the Alps (Sect. 2.1.1), while our kinematic model using Kneller et al. (2012) fits the geological record of rifting and spreading along the Alpine Tethys (Sect. 5.1).

We assume that the Ionian Basin opened in the Triassic (Speranza et al., 2012). However, Tugend et al. (2019) recently re-evaluated the age of the opening of the Ionian Basin as being Late Triassic-Early Jurassic (rifting) and late Early Jurassic-Middle Jurassic (spreading), i.e., overlapping in time with the two first rifting stages of the PL Basin. However, uncertainties remain regarding the exact amount and direction of extension between Africa and Adria that took place at that time. Indeed, the Ionian Basin probably resulted from several phases of extension as indicated for example by the presence of Permian oceanic basins in Sicily (Catalano et al., 1991), and the exact direction and amount of spreading cannot be clearly reconstructed as most of the oceanic domain is now subducted. Nevertheless, we tested an alternative kinematic scenario in which the Ionian Basin (using the presentday total width of ca. $350 \mathrm{~km}$ between the Malta and Apulian escarpments; Tugend et al., 2019, their Fig. 13a) opens and thus Adria (Apulia) moves relative to Africa (Tunisia) in the Early-Middle Jurassic (200-164.7 Ma; Tugend et al., 2019) and in a NW-SE opening direction following Frizon de Lamotte et al. (2011). This would reduce the overlap problem between northern Adria and Sardinia-Corsica mentioned in Sect. 3.2 (Fig. 3). However, it would significantly increase the obliquity of motion between Sardinia-Corsica and Adria (and the rates of motion up to $9 \mathrm{~mm} \mathrm{yr}^{-1}$ ) and therefore reduce considerably the width of the rifted PL domain. Moreover, if we include a significant sinistral strike-slip motion between Africa and Adria during the opening of the Ionian Basin (following the interpretation that the Malta and Apulian escarpments are transform margins; Frizon de Lamotte et al., 2011), Adria would converge towards Sardinia-Corsica rather than diverge, which would be in conflict with the timing of syn-rift deposits and normal faulting along northern Adria (Sect. 2). Future work is therefore required to test such alternative scenarios in more detail. Similarly, as discussed in Sect. 2, a possible Jurassic rifting phase affected the Pyrenees and Valais Basin and would also reduce the width of the rifted PL domain between Europe-Adria. Therefore, our calculated extent of the PL Basin and subsequent amount of convergence (below) constitute maximum estimates.

\subsection{Implications for subduction processes in the Alps}

Using the motion path of NW Adria (Ivrea) relative to Europe, we can estimate the magnitude, direction, and rate of Adria-Europe convergence since the onset of Alpine southdirected subduction at about $84 \mathrm{Ma}$ (Fig. 8; Table 2). Our model indicates a total amount of plate convergence of ca. $680 \mathrm{~km}$ towards the northwest (relative to Europe) since $84 \mathrm{Ma}$. We consider two time periods of two different modes of orogenic processes in the Alps (Sect. 2.2): (1) subduction of both oceanic and extended continental or transitional crust to high depth (marked by (ultra-)high-pressure metamorphism) between ca. 84-35 Ma and (2) continental collision dominated by positive buoyancy of the continental lithosphere after slab break-off at about $35 \mathrm{Ma}$ (Von Blanckenburg and Davies, 1995). Following this definition, the total amount of plate convergence can be subdivided into ca. $420 \mathrm{~km}$ during subduction (84-35 Ma; average rate of $8.6 \mathrm{~mm} \mathrm{yr}^{-1}$ ) and ca. $260 \mathrm{~km}$ during collision (35-0 Ma; average rate of $7.4 \mathrm{~mm} \mathrm{yr}^{-1}$ ). If we take into account that the PL Ocean had a maximum width of $250 \mathrm{~km}$ (in the same NW-SE direction), we can furthermore estimate that at least $63 \%((680-250) / 680 \times 100)$ of the material involved in the Alpine Orogeny was extended continental lithosphere and OCT zones of the PL and Valais basins (Fig. 4). This may explain why the Alps are such a singular mountain belt, e.g., with the absence of well-developed magmatic arc during the alpine subduction (McCarthy et al., 2018, 2020) and widespread high-pressure metamorphosed continent-derived rocks (e.g., Kurz et al., 1999; Berger and Bousquet, 2008; Bousquet et al., 2008; Nagel et al., 2013; Sandmann et al., 2014; Fassmer et al., 2016).

Our estimates of plate convergence are lower than the one obtained from geological reconstructions of the Alps (Handy et al., 2010, 2015), especially for the subduction phase during 84-35 Ma (ca. $200 \mathrm{~km}$ difference; Table 2). The $615 \mathrm{~km}$ of motion obtained by Handy et al. $(2010,2015)$ between 84 and $35 \mathrm{Ma}$ is based on a projection $(465 \mathrm{~km})$ of the estimated ca. $400 \mathrm{~km}$ shortening in the eastern Central Alps from (Schmid et al., 1996) between 67-35 Ma, added to the estimated $150 \mathrm{~km}$ subduction of Sesia between 84 $67 \mathrm{Ma}$ based on the depth of high-pressure nappes of this unit (Babist et al., 2006). A major part of the $400 \mathrm{~km}$ shortening in the Central Alps estimated by Schmid et al. (1996) is itself based on an inferred width of the Valais Basin and Briançonnais that went into subduction between $65-50 \mathrm{Ma}$ and an inferred amount of subduction also based on the depth of high-pressure metamorphism of the Adula Nappe $(150 \mathrm{~km})$ between 50-40 Ma. Two possible sources of error arise and may explain the discrepancy with our results: (1) the past extent of the Valais-Briançonnais domain inferred by Schmid et al. (1996) was not kinematically constrained and (2) the depth of high-pressure rocks - and thus the amount of subduction - may be overestimated due to possible tectonic overpressure (Ford et al., 2006; Schmalholz and Podladchikov, 


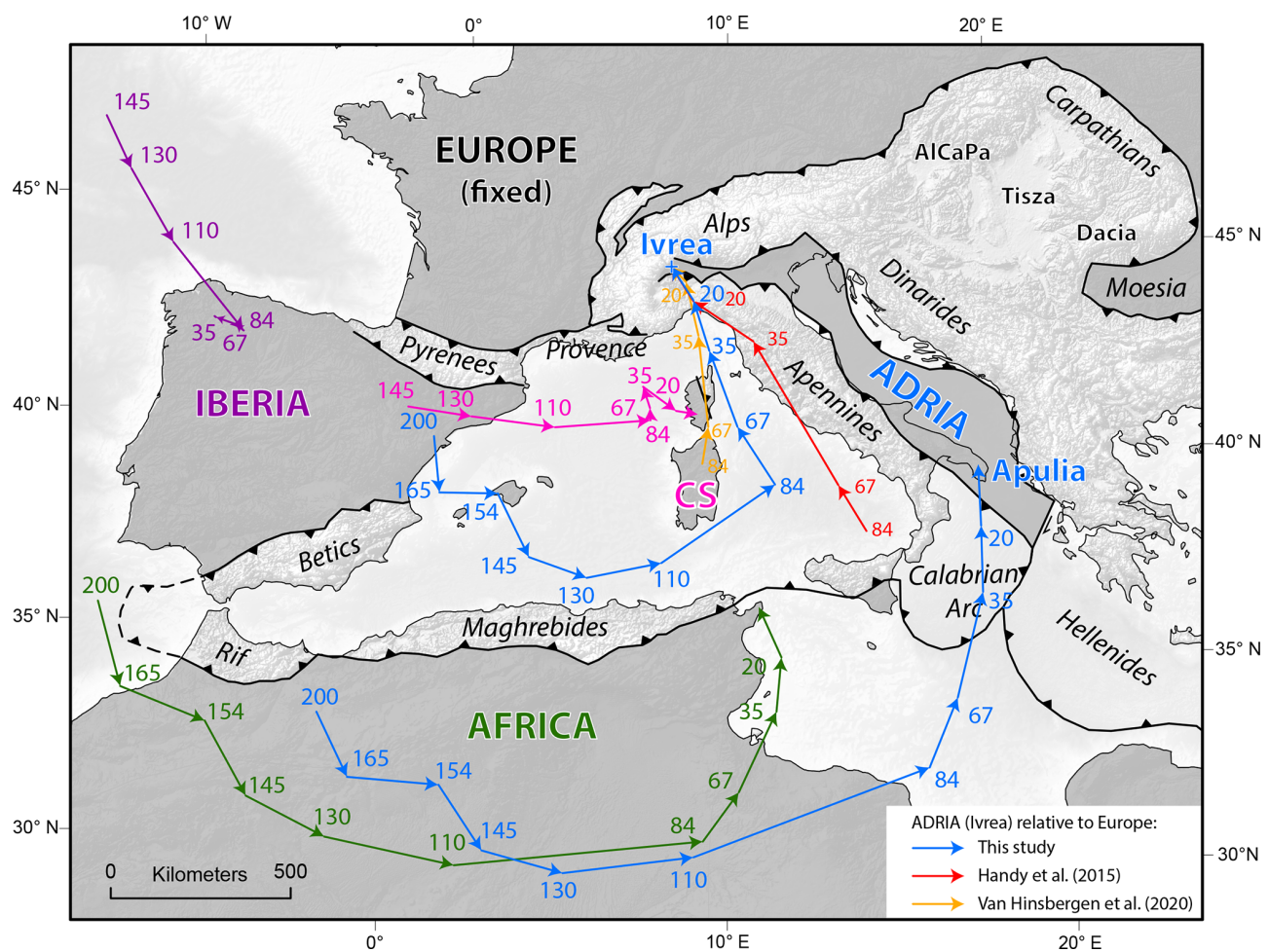

Figure 8. Motion paths of northern (Ivrea) and southern (Apulia) Adria (blue), Iberia (dark purple), Corsica (light purple), and Africa (green) relative to Europe (stationary) back to $200 \mathrm{Ma}$ (time step indicated in millions of years) using our kinematic reconstructions. Alternative motion paths of northern Adria are also shown for comparison (Handy et al., 2015, in red and van Hinsbergen et al., 2020, in orange). Amount, direction, and rate of convergence of Adria (Ivrea)-Europe are given in Table 2.

Table 2. Amount, mean direction (azimuth), and mean rate of Adria (Ivrea)-Europe convergence during Alpine collision (35-0 Ma) and subduction (84-35 Ma). Comparison with the model of Handy et al. (2010, 2015) and van Hinsbergen et al. (2020). Estimates from this study are indicated in bold.

\begin{tabular}{|c|c|c|c|c|}
\hline \multirow[b]{2}{*}{ Time period } & \multicolumn{3}{|c|}{ Adria (Ivrea)-Europe convergence } & \multirow[t]{2}{*}{ Reference } \\
\hline & Amount & Azimuth & Rate & \\
\hline \multirow[t]{3}{*}{ 35-0 Ma; Alpine collision } & $313 \mathrm{~km}$ & $315^{\circ}$ & $8.9 \mathrm{~mm} \mathrm{yr}^{-1}$ & Handy et al. (2015) \\
\hline & $260 \mathrm{~km}$ & $335^{\circ}$ & $7.4 \mathrm{~mm} \mathrm{yr}^{-1}$ & This study \\
\hline & $210 \mathrm{~km}$ & $338^{\circ}$ & $6 \mathrm{~mm} \mathrm{yr}^{-1}$ & van Hinsbergen et al. (2020) \\
\hline \multirow[t]{3}{*}{ 84-35 Ma; Alpine subduction } & $615 \mathrm{~km}$ & $330^{\circ}$ & $12.6 \mathrm{~mm} \mathrm{yr}^{-1}$ & Handy et al. (2015) \\
\hline & $420 \mathrm{~km}$ & $335^{\circ}$ & $8.6 \mathrm{~mm} \mathrm{yr}^{-1}$ & This study \\
\hline & $350 \mathrm{~km}$ & $358^{\circ}$ & $7.1 \mathrm{~mm} \mathrm{yr}^{-1}$ & van Hinsbergen et al. (2020) \\
\hline
\end{tabular}

2013; Pleuger and Podladchikov, 2014; Yamato and Brun, 2017).

We note that our estimates of plate convergence are, however, slightly higher than the recent model proposed by van Hinsbergen et al. (2020; Table 2). This is due to the different assumptions we made for the motion of Iberia, SardiniaCorsica, and Adria as previously discussed (Sect. 3). The major difference impacting the amount and rate of plate convergence is that we consider a sinistral strike-slip motion within Adria of ca. $230 \mathrm{~km}$ along the MF (Fig. 3) between 100-
$40 \mathrm{Ma}$ (Schettino and Turco, 2011; Hosseinpour et al., 2016). This remains poorly constrained and needs to be further studied in the future. Thus, our amounts and rates of plate convergence should be taken as maximum values. We want to emphasize, however, that our assumptions regarding the motion of Iberia (post-145 Ma) and strike-slip motion within Adria (100-40 Ma) do not affect our results and interpretation for the kinematics of the opening (200-145 Ma) and former extent of the PL Ocean and its margins. 
To solve the remaining problematic areas especially regarding the paleomagnetic data from Iberia and Sardinia, future work should focus on quantifying and incorporating into kinematic reconstructions the tectonic deformation within the Iberian and Adriatic plates and between SardiniaCorsica and France. Interestingly, Dannowski et al. (2020) re-evaluated the nature of basement beneath the LiguroProvençal Basin to be hyper-extended continental crust (only a few kilometers thick) and exhumed mantle rather than oceanic crust. Moreover, compressional earthquakes and inverted structures have been observed within the LiguroProvençal Basin and along the northern African margin which suggest that those hyper-extended margins and OCT zones may represent incipient subduction zones accommodating the present-day Africa-Europe convergence (Billi et al., 2011; Hamai et al., 2018; Thorwart et al., 2021). This reflects once more the importance of those domains as an inherited weakness for potential subduction initiation processes (Beltrando et al., 2010; Tugend et al., 2014; Kiss et al., 2020; Zhou et al., 2020).

\section{Conclusions}

In this study, we focused on the divergent Mesozoic history of the Alpine region, which is crucial to better understanding the complex tectonic evolution of this mountain chain. By updating the regional reconstructions of the Western Mediterranean-Alpine area, implemented into a global plate circuit and complemented by thermo-mechanical modeling, we shed new light on the past extent and opening kinematics of the Piemont-Liguria Ocean. The opening of the central Atlantic in Jurassic times led to divergence between Europe and Africa and the opening of the Piemont-Liguria Ocean in four stages. Two successive phases of stretching and thinning of the continental crust $(>10 \mathrm{~km}$ thick, 200-180 Ma; < $10 \mathrm{~km}$ thick, $180-165 \mathrm{Ma}$ ) were followed by mantle exhumation and MORB-type magmatism along the hyper-distal (OCT) part of the margin (165-154 Ma). Mature oceanic spreading in a NW-SE direction (relative to Europe) was short-lived (154-145 Ma) and was slow to ultra-slow (up to $22 \mathrm{~mm} \mathrm{yr}^{-1}$ ), ceasing progressively in the Early Cretaceous (145-130 Ma). This led to the formation of a small mature oceanic domain a maximum of $250 \mathrm{~km}$ wide. This kinematic evolution is in strong agreement with independent geological records of rifting in the Alps and the age of the Alpine Tethys derived units. The opening of the North Atlantic at $145 \mathrm{Ma}$ led to a period of mostly strike-slip tectonics along this domain. South-directed Alpine subduction of the PL Ocean initiated at about $84 \mathrm{Ma}$, at rates of ca. $8.6 \mathrm{~mm} \mathrm{yr}^{-1}$, and progressed from southeast to northwest until collision of the Adriatic Plate with the European proximal margin at about $35 \mathrm{Ma}$. We highlight that at least $63 \%$ of the lithosphere involved in the Alpine Orogeny was highly thinned continental (and transitional) lithosphere and that most of the
Alpine ophiolites were derived from the OCT zones, which emphasizes the importance of the distal domain of continental margins in subduction and exhumation processes. We provide new kinematic constraints (maximum extent of oceanic crust and plate convergence direction and rates) that can be used as setups for future geodynamic modeling and a better understanding of subduction initiation, magmatism, and exhumation processes during the Alpine Orogeny.

Data availability. All reconstruction files of the kinematic model presented in this paper, as well as animations and age grids, are available at https://www.earthbyte.org/webdav/ftp/ Data_Collections/Muller_etal_2019_Tectonics/, last access: 12 April 2021 (Mueller et al., 2019) or by contacting the first author.

Supplement. Results of the 2D thermo-mechanical modeling of the opening of the Piemont-Liguria Basin, using velocities derived from our kinematic reconstructions, are shown in an animation (Movie S1) in the Supplement to this paper. The supplement related to this article is available online at: https://doi.org/10.5194/se-12885-2021-supplement.

Author contributions. ELB developed the research concept, acquired funding, carried out the kinematic reconstructions and their interpretation, designed the figures, and wrote the paper with input from all authors. SB performed the thermo-mechanical modeling and contributed to the interpretation and discussion of the rifting phase. UK participated in the conceptualization of the initial project and in discussion on regional tectonics reconstructions. SZ, MS, and DM were involved in the implementation of the regional kinematic reconstructions into the global deforming plate model using GPlates. SZ and MS generated animations centered on the Mediterranean and age grids of the PL Ocean. DM welcomed ELB for a research stay at the EarthByte Group, University of Sydney, in 2017, which initiated this collaborative work.

Competing interests. The authors declare that they have no conflict of interest.

Special issue statement. This article is part of the special issue "New insights on the tectonic evolution of the Alps and the adjacent orogens". It is not associated with a conference.

Acknowledgements. This work benefited greatly from stimulating conversations with Giancarlo Molli, Jan Pleuger, Mark Handy, members of the AlpArray/4DMB community, and participants of the 14th Emile Argand Conference on Alpine Geological Studies (Alpine Workshop) in Sion in 2019. 
Financial support. Eline Le Breton and Kamil Ustaszewski acknowledge financial support from the German Research Foundation (DFG; BR 4900/2-1 and US 100/4-1). Sascha Brune was funded by the Helmholtz Association through the Helmholtz Young Investigators Group CRYSTALS (VH-NG-1132). Sabin Zahirovic was supported by Australian Research Council grant IH130200012 and a University of Sydney Robinson Fellowship. Maria Seton was supported by Australian Research Council grants FT130101564 and DP200100966. GPlates development is funded by the AuScope National Collaborative Research Infrastructure System (NCRIS) program.

Review statement. This paper was edited by Claudia Piromallo and reviewed by Andrea Argnani and Douwe J. J. van Hinsbergen.

\section{References}

Advokaat, E. L., Van Hinsbergen, D. J. J., Maffione, M., Langereis, C. G., Vissers, R. L. M., Cherchi, A., Schroeder, R., Madani, H., and Columbu, S.: Eocene rotation of Sardinia, and the paleogeography of the western Mediterranean region, Earth Planet. Sci. Lett., 401, 183-195, https://doi.org/10.1016/j.epsl.2014.06.012, 2014.

Amante, C. and Eakins, B. W.: ETOPO1 1 Arc-Minute Global Relief Model, NOAA Technical Memorandum NESDIS NGDC, 24, 19, https://doi.org/10.7289/V5C8276M, 2009.

Andreani, L., Loget, N., Rangin, C., and Pichon, X. Le: New structural constraints on the southern Provence thrust belt (France): Evidences for an eocene shortening event linked to the corsica-sardinia subduction, B. Soc. Geol. Fr., 181, 547-563, https://doi.org/10.2113/gssgfbull.181.6.547, 2010.

Andrés-Martínez, M., Pérez-Gussinyé, M., Armitage, J., and Morgan, J. P.: Thermomechanical Implications of Sediment Transport for the Architecture and Evolution of Continental Rifts and Margins, Tectonics, 38, 641-665, https://doi.org/10.1029/2018TC005346, 2019.

Argnani, A.: Evolution of the southern Tyrrhenian slab tear and active tectonics along the western edge of the Tyrrhenian subducted slab, Geol. Soc. Sp., 311, 193-212, https://doi.org/10.1144/SP311.7, 2009.

Argnani, A.: Plate motion and the evolution of Alpine Corsica and Northern Apennines, Tectonophysics, 579, 207-219, https://doi.org/10.1016/j.tecto.2012.06.010, 2012.

Argnani, A. and Frugoni, F.: Foreland deformation in the Central Adriatic and its bearing on the evolution of the Northern Apennines, Ann. Geofis., XL, 771-780, 1997.

Argnani, A., Rovere, M., and Bonazzi, C.: Tectonics of the Mattinata fault, offshore south Gargano (southern Adriatic Sea, Italy): Implications for active deformation and seismotectonics in the foreland of the Southern Apennines, Bull. Geol. Soc. Am., 121, 1421-1440, https://doi.org/10.1130/B26326.1, 2009.

Babist, J., Handy, M. R., Konrad-Schmolke, M., and Hammerschmidt, K.: Precollisional, multistage exhumation of subducted continental crust: The Sesia Zone, western Alps, Tectonics, 25, 1-25, https://doi.org/10.1029/2005TC001927, 2006.

Ballèvre, M., Manzotti, P., and Dal Piaz, G. V.: Pre-Alpine (Variscan) Inheritance: A Key for the Location of the $\mathrm{Fu}-$ ture Valaisan Basin (Western Alps), Tectonics, 37, 786-817, https://doi.org/10.1002/2017TC004633, 2018.

Barnett-Moore, N., Hosseinpour, M., and Maus, S.: Assessing discrepancies between previous plate kinematic models of Mesozoic Iberia and their constraints, Tectonics, 35, 1843-1862, https://doi.org/10.1002/2015TC004019, 2016.

Barnett-Moore, N., Font, E., and Neres, M.: A Reply to the Comment on "Assessing Discrepancies Between Previous Plate Kinematic Models of Mesozoic Iberia and Their Constraints" by Barnett-Moore Et Al., Tectonics, 36, 3286-3297, https://doi.org/10.1002/2017TC004760, 2017.

Barnett-Moore, N., Müller, D. R., Williams, S., Skogseid, J., and Seton, M.: A reconstruction of the North Atlantic since the earliest Jurassic, Basin Res., 30, 160-185, https://doi.org/10.1111/bre.12214, 2018.

Barrett, T. J. and Spooner, E. T..: Ophiolitic breccias associated with allochtonous oceanic crustal rocks in the east Ligurian Apennines, Italy - A comparison with observations from rifted oceanic ridges, Earth Planet. Sci. Lett., 35, 79-91, 1977.

Beltrando, M., Rubatto, D., Compagnoni, R., and Lister, G.: Was the valaisan basin floored by oceanic crust? Evidence of permian magmatism in the Versoyen unit (Valaisan domain, NW ALPS), Ofioliti, 32, 85-99, https://doi.org/10.7892/boris.85691, 2007.

Beltrando, M., Rubatto, D., and Manatschal, G.: From passive margins to orogens: The link between ocean-continent transition zones and (ultra)high-pressure metamorphism, Geology, 38, 559-562, https://doi.org/10.1130/G30768.1, 2010.

Beltrando, M., Frasca, G., Compagnoni, R., and Vitale-Brovarone, A.: The Valaisan controversy revisited: Multi-stage folding of a Mesozoic hyper-extended margin in the Petit St. Bernard pass area (Western Alps), Tectonophysics, 579, 17-36, https://doi.org/10.1016/j.tecto.2012.02.010, 2012.

Beltrando, M., Manatschal, G., Mohn, G., Dal Piaz, G. V., Vitale Brovarone, A., and Masini, E.: Recognizing remnants of magma-poor rifted margins in high-pressure orogenic belts: The Alpine case study, Earth-Sci. Rev., 131, 88-115, https://doi.org/10.1016/j.earscirev.2014.01.001, 2014.

Berger, A. and Bousquet, R.: Subduction-related metamorphism in the Alps: Review of isotopic ages based on petrology and their geodynamic consequences, Geol. Soc. Sp., 298, 117-144, https://doi.org/10.1144/SP298.7, 2008.

Bernoulli, D. and Jenkyns, H. C.: Ancient oceans and continental margins of the Alpine-Mediterranean Tethys: Deciphering clues from Mesozoic pelagic sediments and ophiolites, Sedimentology, 56, 149-190, https://doi.org/10.1111/j.1365-3091.2008.01017.x, 2009.

Bestani, L., Espurt, N., Lamarche, J., Floquet, M., Philip, J., Bellier, O., and Hollender, F.: Structural style and evolution of the Pyrenean-Provence thrust belt, SE France, B. Soc. Geol. Fr., 186, 223-241, https://doi.org/10.2113/gssgfbull.186.4-5.223, 2015.

Bestani, L., Espurt, N., Lamarche, J., Bellier, O., and Hollender, F.: Reconstruction of the Provence Chain evolution, southeastern France, Tectonics, 35, 1506-1525, https://doi.org/10.1002/2016TC004115, 2016.

Bill, M., O’Dogherty, L., Guex, J., Baumgartner, P. O., and Masson, H.: Radiolarite ages in AlpineMediterranean ophiolites: Constraints on the oceanic spreading and the Tethys-Atlantic connection, Bull. Geol. 
Soc. Am., 113, 129-143, https://doi.org/10.1130/00167606(2001)113<0129:RAIAMO>2.0.CO;2, 2001.

Billi, A., Faccenna, C., Bellier, O., Minelli, L., Neri, G., Piromallo, C., Presti, D., Scrocca, D., and Serpelloni, E.: Recent tectonic reorganization of the Nubia-Eurasia convergent boundary heading for the closure of the western Mediterranean, B. Soc. Geol. Fr., 182, 279-303, https://doi.org/10.2113/gssgfbull.182.4.279, 2011.

Bortolotti, V. and Principi, G.: Tethyan ophiolites and Pangea break-up, Isl. Arc, 14, 442-470, https://doi.org/10.1111/j.14401738.2005.00478.x, 2005.

Bouillin, J. P., Durand-Delga, M., and Olivier, P.: Betic-rifian and tyrrhenian arcs: Distinctive features, genesis and development stages, Developments in Geotectonics, 21, 281-304, https://doi.org/10.1016/B978-0-444-42688-8.50017-5, 1986.

Bousquet, R., Oberhänsli, R., Goffé, B., Wiederkehr, M., Koller, F., Schmid, S. M., Schuster, R., Engi, M., Berger, A., and Martinotti, G.: Metamorphism of metasediments at the scale of an orogen: A key to the Tertiary geodynamic evolution of the Alps, Geol. Soc. Sp., 298, 393-411, https://doi.org/10.1144/SP298.18, 2008.

Bronner, A., Sauter, D., Manatschal, G., Péron-pinvidic, G., and Munschy, M.: Magmatic breakup as an explanation for magnetic anomalies at magma-poor rifted margins, Nat. Geosci., 4, 549553, https://doi.org/10.1038/NGEO1201, 2011.

Brun, J. P. and Faccena, C.: Exhumation of high-pressure rocks driven by slab rollback, Earth Planet. Sc. Lett., 272, 1-7, https://doi.org/10.1016/j.epsl.2008.02.038, 2008.

Brune, S.: Evolution of stress and fault patterns in oblique rift systems: 3-D numerical lithospheric-scale experiments from rift to breakup, Geochem. Geoph. Geosy., 15, 3392-3415, https://doi.org/10.1002/2014GC005446, 2014.

Brune, S., Popov, A. A., and Sobolev, S. V.: Modeling suggests that oblique extension facilitates rifting and continental break-up, J. Geophys. Res., 117, B08402, https://doi.org/10.1029/2011JB008860, 2012.

Brune, S., Popov, A. A., and Sobolev, S. V.: Quantifying the thermo-mechanical impact of plume arrival on continental break-up, Tectonophysics, 604, 51-59, https://doi.org/10.1016/j.tecto.2013.02.009, 2013.

Brune, S., Heine, C., Pérez-Gussinyé, M., and Sobolev, S. V.: Rift migration explains continental margin asymmetry and crustal hyper-extension, Nat. Commun., 5, 1-9, https://doi.org/10.1038/ncomms5014, 2014.

Brune, S., Williams, S. E., Butterworth, N. P., and Müller, R. D.: Abrupt plate accelerations shape rifted continental margins, Nature, 536, 201-204, https://doi.org/10.1038/nature18319, 2016.

Brune, S., Corti, G., and Ranalli, G.: Controls of inherited lithospheric heterogeneity on rift linkage: Numerical and ana$\log$ models of interaction between the Kenyan and Ethiopian rifts across the Turkana depression, Tectonics, 36, 1767-1786, https://doi.org/10.1002/2017TC004739, 2017a.

Brune, S., Heine, C., Clift, P. D., and Perez-Gussinyé, M.: Rifted margin architecture and crustal rheology: Reviewing IberiaNewfoundland, Central South Atlantic, and South China Sea, Mar. Petrol. Geol., 79, 257-281, 2017b.

Brune, S., Williams, S. E., and Müller, R. D.: Oblique rifting: the rule, not the exception, Solid Earth, 9, 1187-1206, https://doi.org/10.5194/se-9-1187-2018, 2018.
Canérot, J.: The pull apart-type Tardets-Mauléon Basin, a key to understand the formation of the Pyrenees, B. Soc. Geol. Fr., 188, 35, https://doi.org/10.1051/bsgf/2017198, 2017.

Castellarin, A., Vai, G. B., and Cantelli, L.: The Alpine evolution of the Southern Alps around the Giudicarie faults: A Late Cretaceous to Early Eocene transfer zone, Tectonophysics, 414, 203 223, https://doi.org/10.1016/j.tecto.2005.10.019, 2006.

Catalano, R., Di Stefano, P., and Kozur, H.: Permian circumpacific deep-water faunas from the western Tethys (Sicily, Italy) new evidences for the position of the Permian Tethys, Palaeogeogr. Palaeocl., 87, 75-108, https://doi.org/10.1016/00310182(91)90131-A, 1991.

Channell, J. E. T. and Kozur, H. W.: How many oceans? Meliata, Vardar, Pindos oceans in Mesozoic Alpine paleogeography, Geology, 25, 183-186, https://doi.org/10.1130/00917613(1997)025<0183:HMOMVA>2.3.CO;2, 1997.

Channell, J. E. T., D'Argenio, B., and Horváth, F.: Adria, the African promontory, in mesozoic Mediterranean palaeogeography, Earth-Sci. Rev., 15, 213-292, https://doi.org/10.1016/00128252(79)90083-7, 1979.

Choukroune, P.: Tectonic evolution of the Pyrenees, Annu. Rev. Earth Planet. Sci., 20, 143-58, 1992.

Cipriani, A. and Bottini, C.: Early Cretaceous tectonic rejuvenation of an Early Jurassic margin in the Central Apennines: The "Mt. Cosce Breccia", Sediment. Geol., 387, 57-74, https://doi.org/10.1016/j.sedgeo.2019.03.002, 2019a.

Cipriani, A. and Bottini, C.: Unconformities, neptunian dykes and mass-transport deposits as an evidence for Early Cretceous synsedimentary tectonics: new insights from the Central Apennines, Ital. J. Geosci., 138, 333-354, 2019b.

Civile, D., Lodolo, E., Accettella, D., Geletti, R., Ben-Avraham, Z., Deponte, M., Facchin, L., Ramella, R., and Romeo, R.: The Pantelleria graben (Sicily Channel, Central Mediterranean): An example of intraplate "passive" rift, Tectonophysics, 490, 173-183, https://doi.org/10.1016/j.tecto.2010.05.008, 2010.

Clerc, C. and Lagabrielle, Y.: Thermal control on the modes of crustal thinning leading to mantle exhumation: Insights from the cretaceous pyrenean hot paleomargins, Tectonics, 33, 13401359, https://doi.org/10.1002/2013TC003471, 2014.

Conti, P., Manatschal, G., and Pfister, M.: Synrift sedimentation, Jurassic and Alpine tectonics in the central Ortler Nappe, (Eastern Alps, Italy), Eclogae Geol. Helv., 87, 63-90, https://doi.org/10.5169/seals-167443, 1994.

Corti, G.: Continental rift evolution: From rift initiation to incipient break-up in the Main Ethiopian Rift, East Africa, Earth-Sci. Rev., 96, 1-53, https://doi.org/10.1016/j.earscirev.2009.06.005, 2009.

Costa, S., and Caby, R.: Evolution of the Ligurian Tethys in the western Alps: $\mathrm{Sm} / \mathrm{Nd}$ and $\mathrm{U} / \mathrm{Pb}$ geochronology and rare-earth element geochemistry of the montgenèvre ophiolite (France), Chem. Geol., 175, 449-466, https://doi.org/10.1016/S00092541(00)00334-X, 2001.

D’Agostino, N., Avallone, A., Cheloni, D., D’Anastasio, E., Mantenuto, S., and Selvaggi, G.: Active tectonics of the Adriatic region from GPS and earthquake slip vectors, J. Geophys. Res.-Sol. Ea., 113, 1-19, https://doi.org/10.1029/2008JB005860, 2008.

Dal Zilio, L., Kissling, E., Gerya, T., and van Dinther, Y.: Slab Rollback Orogeny Model: A Test of Concept, Geophys. Res. Lett., 47, e2020GL089917, https://doi.org/10.1029/2020GL089917, 2020 . 
Dannowski, A., Kopp, H., Klingelhoefer, F., Klaeschen, D., Gutscher, M.-A., Krabbenhoeft, A., Dellong, D., Rovere, M., Graindorge, D., Papenberg, C., and Klaucke, I.: Ionian Abyssal Plain: a window into the Tethys oceanic lithosphere, Solid Earth, 10, 447-462, https://doi.org/10.5194/se-10-447-2019, 2019.

Dannowski, A., Kopp, H., Grevemeyer, I., Lange, D., Thorwart, M., Bialas, J., and Wollatz-Vogt, M.: Seismic evidence for failed rifting in the Ligurian Basin, Western Alpine domain, Solid Earth, 11, 873-887, https://doi.org/10.5194/se-11-873-2020, 2020.

Debroas, E.-J.: Le Flysch noir albo-cénomanien témoin de la structuration albienne à sénonienne de la Zone nord-pyrénéenne en Bigorre (Hautes-Pyrénées, France), B. Soc. Geol. Fr., VI, 273 285, https://doi.org/10.2113/gssgfbull.VI.2.273, 1990.

Decarlis, A., Manatschal, G., Haupert, I., and Masini, E.: The tectono-stratigraphic evolution of distal, hyper-extended magmapoor conjugate rifted margins: Examples from the Alpine Tethys and Newfoundland-Iberia, Mar. Petrol. Geol., 68, 54-72, https://doi.org/10.1016/j.marpetgeo.2015.08.005, 2015.

Decrausaz, T., Müntener, O., Manzotti, P., Lafay R., and Spandler C.: Fossil oceanic core complexes in the Alps. New field, geochemical and isotopic constraints from the Tethyan Aiguilles Rouges Ophiolite (Val d'Hérens, Western Alps, Switzerland), Swiss J. Geosci., 114, 3, https://doi.org/10.1186/s00015020-00380-4, 2021.

Dewey, J. F., Helman, M. L., Knott, S. D., Turco, E., and Hutton, D. H. W.: Kinematics of the western Mediterranean, Geol. Soc. Sp., 45, 265-283, https://doi.org/10.1144/GSL.SP.1989.045.01.15, 1989.

Dick, H. J. B., Lin, J., and Schouten, H.: An ultraslowspreading class of ocean ridge, Nature, 426, 405-412, https://doi.org/10.1038/nature02128, 2003.

Duretz, T., Gerya, T. V., and May, D. A.: Numerical modelling of spontaneous slab breakoff and subsequent topographic response, Tectonophysics, 502, 244-256, https://doi.org/10.1016/j.tecto.2010.05.024, 2011.

Ebinger, C. J., Jackson, J. A., Foster, A. N., and Hayward, N. J.: Extensional basin geometry and the elastic lithosphere, Philos. T. R. Soc. A, 357, 741-765, https://doi.org/10.1098/rsta.1999.0351, 1999.

Epin, M. E., Manatschal, G., Amman, M., Ribes, C., Clausse, A., Guffon, T., and Lescanne, M.: Polyphase tectonomagmatic evolution during mantle exhumation in an ultradistal, magma-poor rift domain: example of the fossil Platta ophiolite, SE Switzerland, Int. J. Earth Sci., 108, 2443-2467, https://doi.org/10.1007/s00531-019-01772-0, 2019.

Espurt, N., Hippolyte, J. C., Saillard, M., and Bellier, O.: Geometry and kinematic evolution of a long-living foreland structure inferred from field data and cross section balancing, the Sainte-Victoire System, Provence, France, Tectonics, 31, 1-27, https://doi.org/10.1029/2011TC002988, 2012.

Faccenna, C., Becker, T. W., Lucente, F. P., Jolivet, L., and Rossetti, F.: History of subduction and back-arc extension in the central Mediterranean, Geophys. J. Int., 145, 809-820, https://doi.org/10.1046/j.0956-540X.2001.01435.x, 2001.

Fassmer, K., Obermüller, G., Nagel, T. J., Kirst, F., Froitzheim, N., Sandmann, S., Miladinova, I., Fonseca, R. O. C., and Münker, C.: High-pressure metamorphic age and significance of eclogite-facies continental fragments associated with oceanic lithosphere in the Western Alps (Etirol-
Levaz Slice, Valtournenche, Italy), Lithos, 252-253, 145-159, https://doi.org/10.1016/j.lithos.2016.02.019, 2016.

Faupl, P. and Tollmann, A.: Die Roßfeldschichten: Ein Beispiel für Sedimentation im Bereich einer tektonisch aktiven Tiefseerinne aus der kalkalpinen Unterkreide, Geol. Rundsch., 68, 93-120, 1979.

Faupl, P. and Wagreich, M.: Late Jurassic to Eocene Palaeogeography and Geodynamic Evolution of the Eastern Alps, Mitteilungen der Österreichischen Geologischen Gesellschaft, 92, 79-94, 1999.

Ferrando, S., Bernoulli, D., and Compagnoni, R.: The Canavese zone (internal Western Alps): A distal margin of Adria, Schweiz. Miner. Petrog., 84, 237-256, 2004.

Florineth, D. and Froitzheim, N.: Transition from continental to oceanic basement in the Tasna nappe (Engadine window, Graubunden, Switzerland): evidence for early Cretaceous opening of the Valais Ocean, Schweiz. Miner. Petrog., 74, 437-448, 1994.

Ford, M., Duchêne, S., Gasquet, D., and Vanderhaeghe, O.: Twophase orogenic convergence in the external and internal SW Alps, J. Geol. Soc., 163, 815-826, https://doi.org/10.1144/001676492005-034, 2006.

Frank, W. and Schlager, W.: Jurassic strike slip versus subduction in the Eastern Alps, Int. J. Earth Sci., 95, 431-450, https://doi.org/10.1007/s00531-005-0045-7, 2006.

Frisch, W.: Tectonic progradation and plate tectonic evolution of the Alps, Tectonophysics, 60, 121-139, https://doi.org/10.1016/0040-1951(79)90155-0, 1979.

Frizon de Lamotte, D., Raulin, C., Mouchot, N., Wrobel-Daveau, J.C., Blanpied, C., and Ringenbach, J.-C.: The southernmost margin of the Tethys realm during the Mesozoic and Cenozoic: Initial geometry and timing of the inversion processes, Tectonics, 30, TC3002, https://doi.org/10.1029/2010tc002691, 2011.

Froitzheim, N.: Synsedimentary and synorogenic normal faults within a thrust sheet of the Eastern Alps (Ortler zone, Graubünden, Switzerland), Eclogae Geol. Helv., 81, 593-610, 1988.

Froitzheim, N. and Eberli, G. P.: Extensional detachment faulting in the evolution of a Tethys passive continental margin, Eastern Alps, Switzerland, Geol. Soc. Am. Bull., 102, 1297-1308, https://doi.org/10.1130/0016-7606(1990)102<1297, 1990.

Froitzheim, N. and Manatschal, G.: Kinematics of Jurassic rifting, mantle exhumation, and passive-margin formation in the Austroalpine and Penninic nappes (eastern Switzerland), Bull. Geol. Soc. Am., 108, 1120-1133, https://doi.org/10.1130/00167606(1996)108<1120:KOJRME>2.3.CO;2, 1996.

Froitzheim, N., Schmid, S. M., and Frey, M.: Mesozoic paleogeography and the timing of eclogite facies metamorphism in the Alps: A working hypothesis, Eclogae Geol. Helv., 89, 81-110, 1996.

Gaina, C., Roest, W. R., and Müller, R. D.: Late CretaceousCenozoic deformation of Northeast Asia, Earth Planet. Sci. Lett., 197, 273-286, https://doi.org/10.1016/S0012-821X(02)00499-5, 2002.

Gattacceca, J., Deino, A., Rizzo, R., Jones, D. S., Henry, B., Beaudoin, B., and Vadeboin, F.: Miocene rotation of Sardinia: New paleomagnetic and geochronological constraints and geodynamic implications, Earth Planet. Sci. Lett., 258, 359-377, https://doi.org/10.1016/j.epsl.2007.02.003, 2007. 
Gawlick, H. J. and Missoni, S.: Middle-Late Jurassic sedimentary mélange formation related to ophiolite obduction in the Alpine-Carpathian-Dinaridic Mountain Range, Gondwana Res., 74, 144-172, https://doi.org/10.1016/j.gr.2019.03.003, 2019.

Gerya, T. V., Stöckhert, B., and Perchuk, A. L.: Exhumation of high-pressure metamorphic rocks in a subduction channel: A numerical simulation, Tectonics, 21, 1056, https://doi.org/10.1029/2002tc001406, 2002.

Guerrera, F., Martin-Algarra, A., and Perrone, V.: Late OligoceneMiocene syn-/-late-orogenic successions in Western and Central Mediterranean Chains from the Betic Cordillera to the Southern Apennines, Terra Nova, 5, 525-544, https://doi.org/10.1111/j.1365-3121.1993.tb00302.x, 1993.

Guerrera, F., Martín-Martín, M., and Tramontana, M.: Evolutionary geological models of the central-western periMediterranean chains: a review, Int. Geol. Rev., 63, 65-86, https://doi.org/10.1080/00206814.2019.1706056, 2019.

Guillot, S. and Ménot, R. P.: Paleozoic evolution of the External Crystalline Massifs of the Western Alps, C. R. Geosci., 341, 253265, https://doi.org/10.1016/j.crte.2008.11.010, 2009.

Guillot, S., Di Paola, S., Ménot, R. P., Ledru, P., Spalla, M. I., Gosso, G., and Schwartz, S.: Suture zones and importance of strike-slip faulting for Variscan geodynamic reconstructions of the External Crystalline Massifs of the western Alps, B. Soc. Geol. Fr., 180, 483-500, https://doi.org/10.2113/gssgfbull.180.6.483, 2009.

Gurnis, M., Turner, M., Zahirovic, S., DiCaprio, L., Spasojevic, S., Müller, R. D., Boyden, J., Seton, M., Manea, V. C., and Bower, D. J.: Plate tectonic reconstructions with continuously closing plates, Comput. Geosci., 38, 35-42, https://doi.org/10.1016/j.cageo.2011.04.014, 2012.

Gurnis, M., Yang, T., Cannon, J., Turner, M., Williams, S., Flament, N., and Müller, R. D.: Global tectonic reconstructions with continuously deforming and evolving rigid plates, Comput. Geosci., 116, 32-41, https://doi.org/10.1016/j.cageo.2018.04.007, 2018.

Hamai, L., Petit, C., Le Pourhiet, L., Yelles-Chaouche, A., Déverchère, J., Beslier, M. O., and Abtout, A.: Towards subduction inception along the inverted North African margin of Algeria? Insights from thermo-mechanical models, Earth Planet. Sci. Lett., 501, 13-23, https://doi.org/10.1016/j.epsl.2018.08.028, 2018.

Handy, M. R., Schmid, S. M., Bousquet, R., Kissling, E., and Bernoulli, D.: Reconciling plate-tectonic reconstructions of Alpine Tethys with the geological-geophysical record of spreading and subduction in the Alps, Earth-Sci. Rev., 102, 121-158, https://doi.org/10.1016/j.earscirev.2010.06.002, 2010.

Handy, M. R., Ustaszewski, K., and Kissling, E.: Reconstructing the Alps-Carpathians-Dinarides as a key to understanding switches in subduction polarity, slab gaps and surface motion, Int. J. Earth Sci., 104, 1-26, https://doi.org/10.1007/s00531-014-10603, 2015.

Hart, N. R., Stockli, D. F., Lavier, L. L., and Hayman, N. W.: Thermal evolution of a hyperextended rift basin, Mauléon Basin, western Pyrenees, Tectonics, 36, 1103-1128, https://doi.org/10.1002/2016TC004365, 2017.

Heine, C., Zoethout, J., and Müller, R. D.: Kinematics of the South Atlantic rift, Solid Earth, 4, 215-253, https://doi.org/10.5194/se4-215-2013, 2013.

Henry, P., Azambre, B., Montigny, R., Rossy, M., and Stevenson, R. K.: Late mantle evolution of the Pyrenean sub-continental litho- spheric mantle in the light of new 40Ar-39Ar and Sm-Nd ages on pyroxenites and periodotites (Pyrenees, France), Tectonophysics, 296, 103-123, https://doi.org/10.1016/S0040-1951(98)00139-5, 1998.

Hermann, J. and Müntener, O.: Extension-related structures in the Malenco-Margna-system: Implications for paleogeography and consequences for rifting and Alpine tectonics, Schweiz. Miner. Petrog., 76, 501-519, https://doi.org/10.5169/seals-57712, 1996.

Horváth, F., Bada, G., Szafián, P., Tari, G., Ádám, A., and Cloetingh, S.: Formation and deformation of the Pannonian Basin: Constraints from observational data, Geo. Soc. Mem., 32, 191206, https://doi.org/10.1144/GSL.MEM.2006.032.01.11, 2006.

Hosseinpour, M., Williams, S., Seton, M., Barnett-Moore, N., and Müller, R. D.: Tectonic evolution of Western Tethys from Jurassic to present day: coupling geological and geophysical data with seismic tomography models, Int. Geol. Rev., 58, 1616-1645, https://doi.org/10.1080/00206814.2016.1183146, 2016.

Huismans, R. S. and Beaumont, C.: Symmetric and asymmetric lithospheric extension: Relative effects of frictional-plastic and viscous strain softening, J. Geophys. Res., 108, 2496, https://doi.org/10.1029/2002JB002026, 2003.

Jammes, S. and Lavier, L. L.: Effect of contrasting strength from inherited crustal fabrics on the development of rifting margins, Geosphere, 15, 407-422, https://doi.org/10.1130/GES01686.1, 2019.

Jammes, S., Manatschal, G., Lavier, L., and Masini, E.: Tectonosedimentary evolution related to extreme crustal thinning ahead of a propagating ocean: Example of the western Pyrenees, Tectonics, 28, 1-24, https://doi.org/10.1029/2008TC002406, 2009.

Johansen, S. E., Panzner, M., Mittet, R., Amundsen, H. E. F., Lim, A., Vik, E., Landrø, M., and Arntsen, B.: Deep electrical imaging of the ultraslow-spreading Mohns Ridge, Nature, 567, 379-383, https://doi.org/10.1038/s41586-019-1010-0, 2019.

Jolivet, L., Faccenna, C., Goffé, B., Mattei, M., Rossetti, F., Brunet, C., Storti, F., Funiciello, R., Cadet, J. P., d'Agostino, N., and Parra, T.: Midcrustal shear zones in postorogenic extension: Example from the northern Tyrrhenian Sea, J. Geophys. Res.Sol. Ea., 103, 12123-12160, https://doi.org/10.1029/97jb03616, 1998.

Jolivet, L., Gorini, C., Smit, J., and Leroy, S.: back-arc basins: the Gulf of Lion margin, Tectonics, 34, 662-679, https://doi.org/10.1002/2014TC003570, 2015.

Joseph, P., Cabrol, C., and Friès, G.: Titled blocks and submarine passes in the Banon graben (France, SE) during Apto-Albian times: a paleotopography directly induced by strike-slip synsedimentary tectonics, C. R. Acad. Sci. II A, 304, 447-452, 1987.

Kaczmarek, M. A., Müntener, O., and Rubatto, D.: Trace element chemistry and $\mathrm{U}-\mathrm{Pb}$ dating of zircons from oceanic gabbros and their relationship with whole rock composition (Lanzo, Italian Alps), Contrib. Mineral. Petr., 155, 295-312, https://doi.org/10.1007/s00410-007-0243-3, 2008.

Kästle, E. D., Rosenberg, C., Boschi, L., Bellahsen, N., Meier, T., and El-Sharkawy, A.: Slab break-offs in the Alpine subduction zone, Int. J. Earth Sci., 109, 587-603, https://doi.org/10.1007/s00531-020-01821-z, 2020.

Kiss, D., Candioti, L. G., Duretz, T., and Schmalholz, S. M.: Thermal softening induced subduction initiation at a passive margin, Geophys. J. Int., 220, 2068-2073, https://doi.org/10.1093/gji/ggz572, 2020. 
Kneller, E. A., Johnson, C. A., Karner, G. D., Einhorn, J., and Queffelec, T. A.: Inverse methods for modeling non-rigid plate kinematics: Application to mesozoic plate reconstructions of the Central Atlantic, Comput. Geosci., 49, 217-230, https://doi.org/10.1016/j.cageo.2012.06.019, 2012.

Kurz, W., Neubauer, F., and Unzog, W.: Evolution of Alpine eclogites in the Eastern Alps: Implications for Alpine Geodynamics, Phys. Chem. Earth Pt. A, 24, 667-674, https://doi.org/10.1016/S1464-1895(99)00097-6, 1999.

Labails, C., Olivet, J.-L., Aslanian, D., and Roest, W. R.: An alternative early opening scenario for the Central Atlantic Ocean, Earth Planet. Sci. Lett., 297, 355-368, https://doi.org/10.1016/j.eps1.2010.06.024, 2010.

Lacombe, O. and Jolivet, L.: Structural and kinematic relationships between Corsica and the Pyrenees-Provence domain at the time of the Pyrenean orogeny, Tectonics, 24, 1-20, https://doi.org/10.1029/2004TC001673, 2005.

Lagabrielle, Y. and Cannat, M.: Alpine Jurassic ophiolites resemble the modern central Atlantic basement, Geology, 18, 319-322, 1990.

Lagabrielle, Y. and Lemoine, M.: Alpine, Corsican and Apennine ophiolites: the slow-spreading ridge model, C. R. Acad. Sci. II A, 325, 909-920, 1997.

Lahondère, D. and Guerrot, C.: Datation Sm-Nd du métamorphisme éclogitique en Corse alpine: un argument pour l'existence au Crétacé supérieur d'une zone de subduction active localisée sous le bloc corso-sarde, Géologie de la France, 3, 3-11, 1997.

Lavier, L. L. and Manatschal, G.: A mechanism to thin the continental lithosphere at magma-poor margins, Nature, 440, 324-328, https://doi.org/10.1038/nature04608, 2006.

Le Breton, E., Handy, M. R., Molli, G., and Ustaszewski, K.: Post-20 Ma Motion of the Adriatic Plate: New Constraints From Surrounding Orogens and Implications for Crust-Mantle Decoupling, Tectonics, 36, 3135-3154, https://doi.org/10.1002/2016TC004443, 2017.

Le Pichon, X., Bergerat, F., and Roulet, M.-J.: Plate kinematics and tectonics leading to the Alpine belt formation; A new analysis, Geol. S. Am. S., 111-131, 1988.

Lemoine, M., Bas, T., Arnaud-Vanneau, A., Arnaud, H., Dumont, T., Gidon, M., Bourbon, M., de Graciansky, P.-C., Rudkiewicz, J.-L., Megard-Galli, J., and Tricart, P..: The continental margin of the Mesozoic Tethys in the Western Alps, Mar. Petrol. Geol., 3, 179-199, https://doi.org/10.1016/0264-8172(86)90044-9, 1986.

Li, X. H., Faure, M., Lin, W., and Manatschal, G.: New isotopic constraints on age and magma genesis of an embryonic oceanic crust: The Chenaillet Ophiolite in the Western Alps, Lithos, 160-161, 283-291, https://doi.org/10.1016/j.lithos.2012.12.016, 2013.

Liati, A. and Froitzheim, N.: Assessing the Valais ocean, Western Alps: U-Pb SHRIMP zircon geochronology of eclogite in the Balma unit, on top of the Monte Rosa nappe, Eur. J. Mineral., 18, 299-308, https://doi.org/10.1127/09351221/2006/0018-0299, 2006.

Liati, A., Froitzheim, N., and Fanning, C. M.: Jurassic ophiolites within the Valais domain of the Western and Central Alps: Geochronological evidence for re-rifting of oceanic crust, Contrib. Mineral. Petr., 149, 446-461, https://doi.org/10.1007/s00410-005-0658-7, 2005.
Loprieno, A., Bousquet, R., Bucher, S., Ceriani, S., Dalla Torre, F. H., Fügenschuh, B., and Schmid, S. M.: The Valais units in Savoy (France): A key area for understanding the palaeogeography and the tectonic evolution of the Western Alps, Int. J. Earth Sci., 100, 963-992, https://doi.org/10.1007/s00531-010-0595-1, 2011.

Macchiavelli, C., Vergés, J., Schettino, A., Fernàndez, M., Turco, E., Casciello, E., Torne, M., Pierantoni, P. P., and Tunini, L.: A New Southern North Atlantic Isochron Map: Insights Into the Drift of the Iberian Plate Since the Late Cretaceous, J. Geophys. Res.-Sol. Ea., 122, 9603-9626, https://doi.org/10.1002/2017JB014769, 2017.

Maffione, M. and van Hinsbergen, D. J. J.: Reconstructing Plate Boundaries in the Jurassic Neo-Tethys From the East and West Vardar Ophiolites (Greece and Serbia), Tectonics, 37, 858-887, https://doi.org/10.1002/2017TC004790, 2018.

Manatschal, G.: New models for evolution of magma-poor rifted margins based on a review of data and concepts from West Iberia and the Alps, Int. J. Earth Sci., 93, 432-466, https://doi.org/10.1007/s00531-004-0394-7, 2004.

Manatschal, G. and Bernoulli, D.: Architecture and tectonic evolution of nonvolcanic margins: Present-day Galicia and ancient Adria, Tectonics, 18, 1099-1119, https://doi.org/10.1029/1999TC900041, 1999.

Manatschal, G. and Müntener, O.: A type sequence across an ancient magma-poor ocean-continent transition: the example of the western Alpine Tethys ophiolites, Tectonophysics, 473, 4-19, https://doi.org/10.1016/j.tecto.2008.07.021, 2009.

Manatschal, G., Engström, A., Desmurs, L., Schaltegger, U., Cosca, M., Müntener, O., and Bernoulli, D.: What is the tectonometamorphic evolution of continental break-up: The example of the Tasna Ocean-Continent Transition, J. Struct. Geol., 28, 18491869, https://doi.org/10.1016/j.jsg.2006.07.014, 2006.

Manzotti, P., Ballèvre, M., Zucali, M., Robyr, M., and Engi, M.: The tectonometamorphic evolution of the Sesia-Dent Blanche nappes (internal Western Alps): review and synthesis, Swiss J. Geosci., 107, 309-336, https://doi.org/10.1007/s00015-0140172-x, 2014.

Manzotti, P., Bosse, V., Pitra, P., Robyr, M., Schiavi, F., and Ballèvre, M.: Exhumation rates in the Gran Paradiso Massif (Western Alps) constrained by in situ $\mathrm{U}-\mathrm{Th}-\mathrm{Pb}$ dating of accessory phases (monazite, allanite and xenotime), Contrib. Mineral. Petr., 173, 1-28, https://doi.org/10.1007/s00410-018-1452-7, 2018.

Marroni, M., Monechi, S., Perilli, N., Principi, G., and Treves, B.: Late Cretaceous flysch deposits of the Northern Apennines, Italy: age of inception of orogenesis-controlled sedimentation, Cretaceous Res., 13, 487-504, https://doi.org/10.1016/01956671(92)90013-G, 1992.

Marroni, M., Molli, G., Montanini, A., and Tribuzio, R.: The association of continental crust rocks with ophiolites in the northern Apennines (Italy): implications for the continent-ocean transition in the Western Tethys, Tectonophysics, 292, 43-66, https://doi.org/10.1016/S0040-1951(98)00060-2, 1998.

Martin, L. A. J., Rubatto, D., Vitale Brovarone, A., and Hermann, J.: Late Eocene lawsonite-eclogite facies metasomatism of a granulite sliver associated to ophiolites in Alpine Corsica, Lithos, 125, 620-640, https://doi.org/10.1016/j.lithos.2011.03.015, 2011.

Masetti, D., Fantoni, R., Romano, R., Sartorio, D., and Trevisani, E.: Tectonostratigraphic evolution of the Jurassic extensional 
basins of the eastern southern Alps and Adriatic foreland based on an integrated study of surface and subsurface data, AAPG Bull., 96, 2065-2089, https://doi.org/10.1306/03091211087, 2012.

Masini, E., Manatschal, G., and Mohn, G.: The Alpine Tethys rifted margins: Reconciling old and new ideas to understand the stratigraphic architecture of magma-poor rifted margins, Sedimentology, 60, 174-196, https://doi.org/10.1111/sed.12017, 2013.

Masini, E., Manatschal, G., Tugend, J., Mohn, G., and Flament, J. M.: The tectono-sedimentary evolution of a hyper-extended rift basin: The example of the Arzacq-Mauléon rift system (Western Pyrenees, SW France), Int. J. Earth Sci., 103, 1569-1596, https://doi.org/10.1007/s00531-014-1023-8, 2014.

Masson, H., Bussy, F., Eichenberger, M., Giroudd, N., Meilhac, C., and Presniakov, S.: Early Carboniferous age of the Versoyen ophiolites and consequences: Non-existence of a "Valais ocean" (Lower Penninic, western Alps), B. Soc. Geol. Fr., 179, 337-355, https://doi.org/10.2113/gssgfbull.179.4.337, 2008.

Matte, P.: The Variscan collage and orogeny (480-290 Ma) and the tectonic definition of the Armorica microplate: A review, Terra Nova, 13, 122-128, https://doi.org/10.1046/j.13653121.2001.00327.x, 2001.

Matter, A., Homewood, P., Caron, C., Rigassi, D., Van Stuijvenberg, J., Weidmann, M., and Winkler, W.: Flysch and Molasse of Western and Central Switzerland: Geology of Switzerland, a Guide Book, edited by: Schweizerische Geologische Kommission, Wepf \& Co. Publishers, Basel, New York, 261-293, 1980.

McCarthy, A., Chelle-Michou, C., Müntener, O., Arculus, R., and Blundy, J.: Subduction initiation without magmatism: The case of the missing Alpine magmatic arc, Geology, 46, 1059-1062, https://doi.org/10.1130/G45366.1, 2018.

McCarthy, A., Tugend, J., Mohn, G., Candioti, L., ChelleMichou, C., Arculus, R., Schmalholz, S. M., and Müntener, O.: A case of Ampferer-type subduction and consequences for the Alps and the Pyrenees, Am. J. Sci., 320, 313-372, https://doi.org/10.2475/04.2020.01, 2020.

McClay, K., Munoz, J. A., and García-Senz, J.: Extensional salt tectonics in a contractional orogen: A newly identified tectonic event in the Spanish Pyrenees, Geology, 32, 737-740, https://doi.org/10.1130/G20565.1, 2004.

McKenzie, D.: Some remarks on the development of sedimentary basins, Earth Planet. Sci. Lett., 40, 25-32, https://doi.org/10.1016/0012-821X(78)90071-7, 1978.

Michard, A., Chalouan, A., Feinberg, H., Goffé, B., and Montigny, R.: How does the Alpine belt end between Spain and Morocco?, B. Soc. Geol. Fr., 173, 3-15, https://doi.org/10.2113/173.1.3, 2002.

Michard, A., Negro, F., Saddiqi, O., Bouybaouene, M. L., Chalouan, A., Montigny, R., and Goffé, B.: Pressuretemperature-time constraints on the Maghrebide mountain building: Evidence from the Rif-Betic transect (Morocco, Spain), Algerian correlations, and geodynamic implications, C. R. Geosci., 338, 92-114, https://doi.org/10.1016/j.crte.2005.11.011, 2006.

Michard, A., Mokhtari, A., Chalouan, A., Saddiqi, O., Rossi, P., and Rjimati, E. C.: New ophiolite slivers in the External Rif belt, and tentative restoration of a dual Tethyan suture in the western Maghrebides, B. Soc. Geol. Fr., 185, 313-328, https://doi.org/10.2113/gssgfbull.185.5.313, 2014.
Mohn, G., Manatschal, G., Müntener, O., Beltrando, M., and Masini, E.: Unravelling the interaction between tectonic and sedimentary processes during lithospheric thinning in the Alpine Tethys margins, Int. J. Earth Sci., 99, 75-101, https://doi.org/10.1007/s00531-010-0566-6, 2010.

Mohn, G., Manatschal, G., Beltrando, M., Masini, E., and Kusznir, N.: Necking of continental crust in magma-poor rifted margins: Evidence from the fossil Alpine Tethys margins, Tectonics, 31, 1-28, https://doi.org/10.1029/2011TC002961, 2012.

Molli, G.: Northern Apennine-Corsica orogenic system: An updated overview, Geol. Soc. Sp., 298, 413-442, https://doi.org/10.1144/SP298.19, 2008.

Molli, G. and Malavieille, J.: Orogenic processes and the Corsica/Apennines geodynamic evolution: insights from Taiwan, Int. J. Earth Sci., 100, 1207-1224, https://doi.org/10.1007/s00531010-0598-y, 2011.

Molli, G., Brogi, A., Caggianelli, A., Capezzuoli, E., Liotta, D., Spina, A., and Zibra, I.: Late Palaeozoic tectonics in Central Mediterranean: a reappraisal, Swiss J. Geosci., 113, 1-32, https://doi.org/10.1186/s00015-020-00375-1, 2020.

Montenat, C., Janin, M. C., and Barrier, P.: L'accident $\mathrm{du}$ Toulourenc: Une limite tectonique entre la plateforme provençale et le Bassin vocontien à l'AptienAlbien (SE France), C. R. Geosci., 336, 1301-1310, https://doi.org/10.1016/j.crte.2004.05.002, 2004.

Moulas, E., Schmalholz, S. M., Podladchikov, Y., Tajčmanová, L., Kostopoulos, D., and Baumgartner, L.: Relation between mean stress, thermodynamic, and lithostatic pressure, J. Metamorph. Geol., 37, 1-14, https://doi.org/10.1111/jmg.12446, 2019.

Mouthereau, F., Filleaudeau, P. Y., Vacherat, A., Pik, R., Lacombe, O., Fellin, M. G., Castelltort, S., Christophoul, F., and Masini, E.: Placing limits to shortening evolution in the Pyrenees: Role of margin architecture and implications for the Iberia/Europe convergence, Tectonics, 33, 2283-2314, https://doi.org/10.1002/2014TC003663, 2014.

Müller, R. D., Roest, W. R., Royer, J.-Y., Gahagan, L. M., and Sclater, J. G.: Digital isochrons of the world's ocean floor, J. Geophys. Res.-Sol. Ea., 102, 3211-3214, https://doi.org/10.1029/96jb01781, 1997.

Müller, R. D., Royer, J. Y., Cande, S. C., Roest, W. R., and Maschenkov, S.: New constraints on the late cretaceous/tertiary plate tectonic evolution of the caribbean, Sedimentary Basins of the World, 4, 33-59, https://doi.org/10.1016/S18745997(99)80036-7, 1999.

Müller, R. D., Cannon, J., Qin, X., Watson, R. J., Gurnis, M., Williams, S., Pfaffelmoser, T., Seton, M., Russell, S. H. J., and Zahirovic, S.: GPlates: Building a Virtual Earth Through Deep Time, Geochem., Geophy., Geosy., 19, 22432261, https://doi.org/10.1029/2018GC007584, 2018.

Müller, R. D., Zahirovic, S., Williams, S. E., Cannon, J., Seton, M., Bower, D. J., Tetley, M. G., Heine, C., Le Breton, E., Liu, S., Russel, S. H. J., Yang, T., Leonard, J., and Gurnis, M.: A Global Plate Model Including Lithospheric Deformation Along Major Rifts and Orogens Since the Triassic, Tectonics, 38, 1884-1907, https://doi.org/10.1029/2018TC005462, 2019.

Müntener, O. and Hermann, J.: The role of lower crust and continental upper mantle during formation of non-volcanic passive margins: Evidence from the Alps, Geol. Soc. Sp., 187, 267-288, https://doi.org/10.1144/GSL.SP.2001.187.01.13, 2001. 
Nagel, T. J., Herwartz, D., Rexroth, S., Münker, C., Froitzheim, N., and Kurz, W.: Lu-Hf dating, petrography, and tectonic implications of the youngest Alpine eclogites (Tauern Window, Austria), Lithos, 170-171, 179-190, https://doi.org/10.1016/j.lithos.2013.02.008, 2013.

Neres, M., Font, E., Miranda, J. M., Camps, P., Terrinha, P., and Mirão, J.: Reconciling Cretaceous paleomagnetic and marine magnetic data for Iberia: New Iberian paleomagnetic poles, J. Geophys. Res.-Sol. Ea., 117, 1-21, https://doi.org/10.1029/2011JB009067, 2012.

Neres, M., Miranda, J. M., and Font, E.: Testing Iberian kinematics at Jurassic-Cretaceous times, Tectonics, 32, 1312-1319, https://doi.org/10.1002/tect.20074, 2013.

Neubauer, F., Dallmeyer, R. D., Dunkl, I., and Schirnik, D.: Late Cretaceous exhumation of the metamorphic Gleinalm dome, Eastern Alps: kinematics, cooling history and sedimenetary response in a sinistral wrench corridor, Tectonophysics, 242, 7998, https://doi.org/10.1016/0040-1951(94)00154-2, 1995.

Nirrengarten, M., Manatschal, G., Tugend, J., Kusznir, N. J., and Sauter, D.: Nature and origin of the J-magnetic anomaly offshore Iberia-Newfoundland: implications for plate reconstructions, Terra Nova, 29, 20-28, https://doi.org/10.1111/ter.12240, 2017.

Oliva-Urcia, B., Casas, A. M., Soto, R., Villalaín, J. J., and Kodama, K.: A transtensional basin model for the Organyà basin (central southern Pyrenees) based on magnetic fabric and brittle structures, Geophys. J. Int., 184, 111-130, https://doi.org/10.1111/j.1365-246X.2010.04865.x, 2011.

Olivet, J.: La cinématique de la plaque ibérique, B. Cent. Rech. Expl., 20, 131-195, 1996.

Pérez-Gussinyé, M., Morgan, J. P., Reston, T. J., and Ranero, C. R.: The rift to drift transition at non-volcanic margins: Insights from numerical modelling, Earth Planet. Sci. Lett., 244, 458473, https://doi.org/10.1016/j.epsl.2006.01.059, 2006.

Peybernés, B. and Souquet, P.: Basement blocks and tecto-sedimentary evolution in the Pyrenees during Mesozoic times, Geol. Mag., 121, 397-405, https://doi.org/10.1017/S0016756800029927, 1984.

Picazo, S., Müntener, O., Manatschal, G., Bauville, A., Karner, G., and Johnson, C.: Mapping the nature of mantle domains in Western and Central Europe based on clinopyroxene and spinel chemistry: Evidence for mantle modification during an extensional cycle, Lithos, 266-267, 233-263, https://doi.org/10.1016/j.lithos.2016.08.029, 2016.

Piccardo, G. B. and Guarnieri, L.: Alpine peridotites from the Ligurian Tethys: An updated critical review, Int. Geol. Rev., 52, 1138-1159, https://doi.org/10.1080/00206810903557829, 2010.

Pleuger, J. and Podladchikov, Y. Y.: A purely structural restoration of the NFP20-East cross section and potential tectonic overpressure in the Adula nappe (central Alps), Tectonics, 33, 656-685, https://doi.org/10.1002/2013TC003409, 2014.

Popov, A. A. and Sobolev, S. V.: SLIM3D: A tool for threedimensional thermomechanical modeling of lithospheric deformation with elasto-visco-plastic rheology, Phys. Earth Planet. In., 171, 55-75, https://doi.org/10.1016/j.pepi.2008.03.007, 2008.

Ratschbacher, L., Merle, O., Davy, P., and Cobbold, P.: Lateral extrusion in the Eastern Alps, Part 1: boundary conditions and experiments scaled for gravity, Tectonics, 10, 245-256, 1991.
Reuber, G., Kaus, B. J. P., Schmalholz, S. M., and White, R. W.: Nonlithostatic pressure during subduction and collision and the formation of (ultra)high-pressure rocks, Geology, 44, 343-346, https://doi.org/10.1130/G37595.1, 2016.

Ribes, C., Manatschal, G., Ghienne, J. F., Karner, G. D., Johnson, C. A., Figueredo, P. H., Incerpi, N., and Epin, M. E.: The syn-rift stratigraphic record across a fossil hyper-extended rifted margin: the example of the northwestern Adriatic margin exposed in the Central Alps, Int. J. Earth Sci., 108, 2071-2095, https://doi.org/10.1007/s00531-019-01750-6, 2019.

Ribes, C., Petri, B., Ghienne, J. F., Manatschal, G., Galster, F., Karner, G. D., Figueredo, P. H., Johnson, C. A., and Karpoff, A. M.: Tectono-sedimentary evolution of a fossil ocean-continent transition: Tasna nappe, central Alps (SE Switzerland), Bull. Geol. Soc. Am., 132, 1427-1446, https://doi.org/10.1130/B35310.1, 2020.

Rosenbaum, G., Lister, G. S., and Duboz, C.: Rewlative mortiosn of Frica, Iberia and europe during Alpine orogeny, Tectonophysics, 359, 117-129, 2002.

Rosenbaum, G. and Lister, G. S.: Neogene and Quaternary rollback evolution of the Tyrrhenian Sea, the Apennines, and the Sicilian Maghrebides, Tectonics, 23, TC1013, https://doi.org/10.1029/2003TC001518, 2004.

Rosenberg, C. L.: Shear zones and magma ascent: A model based on a review of the Tertiary magmatism in the Alps, Tectonics, 23, TC3002, https://doi.org/10.1029/2003TC001526, 2004.

Royden, L. and Burchfiel, B. C.: Are systematic variations in thrust belt style related to plate boundary processes? (The western Alps versus the Carpathians), Tectonics, 8, 51-61, https://doi.org/10.1029/TC008i001p00051, 1989.

Rubatto, D., Gebauer, D., and Fanning, M.: Jurassic formation and Eocene subduction of the Zermatt-Saas-Fee ophiolites: Implications for the geodynamic evolution of the Central and Western Alps, Contrib. Mineral. Petr., 132, 269-287, https://doi.org/10.1007/s004100050421, 1998.

Ruh, J. B., Le Pourhiet, L., Agard, P., Burov, E., and Gerya, T.: Tectonic slicing of subducting oceanic crust along plate interfaces: Numerical modeling, Geochem., Geophy., Geosy., 16, 35053531, https://doi.org/10.1002/2015GC005998, 2015.

Sandmann, S., Nagel, T. J., Herwartz, D., Fonseca, R. O. C., Kurzawski, R. M., Münker, C., and Froitzheim, N.: Lu-Hf garnet systematics of a polymetamorphic basement unit: new evidence for coherent exhumation of the Adula Nappe (Central Alps) from eclogite-facies conditions, Contrib. Mineral. Petr., 168, 1-21, https://doi.org/10.1007/s00410-014-1075-6, 2014.

Scharf, A., Handy, M. R., Favaro, S., Schmid, S. M., and Bertrand, A.: Modes of orogen-parallel stretching and extensional exhumation in response to microplate indentation and roll-back subduction (Tauern Window, Eastern Alps), Int. J. Earth Sci., 102, 1627-1654, https://doi.org/10.1007/s00531-013-0894-4, $2013 \mathrm{a}$.

Scharf, A., Handy, M. R., Ziemann, M. A., and Schmid, S. M.: Peak-temperature patterns of polyphase metamorphism resulting from accretion, subduction and collision (eastern tauern window, european alps) - a study with raman microspectroscopy on carbonaceous material (RSCM), J. Metamorph. Geol., 31, 863-880, https://doi.org/10.1111/jmg.12048, 2013b.

Schettino, A. and Scotese, C. R.: Apparent polar wander paths for the major continents (200 Ma to the present day): A palaeomagnetic reference frame for global plate tectonic reconstructions, 
Geophys. J. Int., 163, 727-759, https://doi.org/10.1111/j.1365246X.2005.02638.x, 2005.

Schettino, A. and Turco, E.: Tectonic history of the Western Tethys since the Late Triassic, Bull. Geol. Soc. Am., 123, 89-105, https://doi.org/10.1130/B30064.1, 2011.

Schmalholz, S. M. and Podladchikov, Y. Y.: Tectonic overpressure in weak crustal-scale shear zones and implications for the exhumation of high-pressure rocks, Geophys. Res. Lett., 40, 1984 1988, https://doi.org/10.1002/grl.50417, 2013.

Schmid, S. M., Pfiffner, O. A., Froitzheim, N., Schönborn, G., and Kissling, E.: Geophysical-geological transect and tectonic evolution of the Swiss-Italian Alps, Tectonics, 15, 1036-1064, https://doi.org/10.1029/96TC00433, 1996.

Schmid, S. M., Bernoulli, D., Fügenschuh, B., Matenco, L., Schefer, S., Schuster, R., Tischler, M., and Ustaszewski, K.: The Alpine-Carpathian-Dinaridic orogenic system: Correlation and evolution of tectonic units, Swiss J. Geosci., 101, 139-183, https://doi.org/10.1007/s00015-008-1247-3, 2008.

Schmid, S. M., Fügenschuh, B., Kounov, A., Matenco, L., Nievergelt, P., Oberhänsli, R., Pleuger, J., Schefer, S., Schuster, R., Tomljenovic, B., Ustaszewski, K., and van Hinsbergen, D. J. J.: Tectonic units of the Alpine collision zone between Eastern Alps and western Turkey, Gondwana Res., 78, 308-374, https://doi.org/10.1016/j.gr.2019.07.005, 2020.

Schuster, R. and Frank, W.: Metamorphic evolution of the Austroalpine units east of the Tauern Window, Mitt. Geol. Bergbau Stud. Österr., 42, 37-58, 1999.

Scisciani, V. and Calamita, F.: Active intraplate deformation within Adria: Examples from the Adriatic region, Tectonophysics, 476, 57-72, https://doi.org/10.1016/j.tecto.2008.10.030, 2009.

Séranne, M.: The Gulf of Lion continental margin (NW Mediterranean) revisited by IBS: an overview, Geol. Soc. Sp., 156, 1536, https://doi.org/10.1144/GSL.SP.1999.156.01.03, 1999.

Sibuet, J.-C., Srivastav, S. P., and Spakman, W.: Pyrenean orogeny and plate kinematics, J. Geophys. Res., 109, 1-18, https://doi.org/10.1029/2003JB002514, 2004.

Sieberer, A.-K. and Ortner, H.: Influence of Penninic rifting on the tectonic evolution of the northern Austroalpine margin, GeoUtrecht 2020, 24-26 August 2020, Utrecht, the Netherlands, https://www.conftool.pro/geoutrecht2020/index.php?page= browseSessions\&form_session=159, 296, 2020.

Sinclair, H. D.: Tectonostratigraphic model for underfilled peripheral foreland basins: An Alpine perspective, Bull. Geol. Soc. Am., 109, 324-346, https://doi.org/10.1130/00167606(1997)109<0324:TMFUPF>2.3.CO;2, 1997.

Spakman, W., Chertova, M. V., Van Den Berg, A., and Van Hinsbergen, D. J. J.: Puzzling features of western Mediterranean tectonics explained by slab dragging, Nat. Geosci., 11, 211-216, https://doi.org/10.1038/s41561-018-0066-z, 2018.

Speranza, F., Villa, I. M., Sagnotti, L., Florindo, F., Cosentino, D., Cipollari, P., and Mattei, M.: Age of the Corsica-Sardinia rotation and Liguro-Provençal Basin spreading: New paleomagnetic and Ar/Ar evidence, Tectonophysics, 347, 231-251, https://doi.org/10.1016/S0040-1951(02)00031-8, 2002.

Speranza, F., Minelli, L., Pignatelli, A., and Chiappini, M.: The Ionian Sea: The oldest in situ ocean fragment of the world?, J. Geophys. Res.-Sol. Ea., 117, 1-13, https://doi.org/10.1029/2012JB009475, 2012.
Srivastava, S. P., Roest, W. R., Kovacs, L. C., Oakey, G., Lévesque, S., Verhoef, J., and Macnab, R.: Motion of Iberia since the Late Jurassic: Results from detailed aeromagnetic measurements in the Newfoundland Basin, Tectonophysics, 184, 229-260, https://doi.org/10.1016/0040-1951(90)90442-B, 1990.

Stampfli, G. M.: Le Briançonnais, terrain exotique dans les Alpes?, Eclogae Geol. Helv., 86, 1-45, 1993.

Stampfli, G. M. and Borel, G. D.: A plate tectonic model for the Paleozoic and Mesozoic constrained by dynamic plate boundaries and restored synthetic oceanic isochrons, Earth Planet. Sci. Lett., 196, 17-33, https://doi.org/10.1016/S0012-821X(01)00588-X, 2002.

Stampfli, G. M., Mosar, J., Marquer, D., Marchant, R., Baudin, T., and Borel, G.: Subduction and obduction processes in the Swiss Alps, Tectonophysics, 296, 159-204, https://doi.org/10.1016/S0040-1951(98)00142-5, 1998.

Stern, R. J. and Gerya, T.: Subduction initiation in nature and models: A review, Tectonophysics, 746, 173-198, https://doi.org/10.1016/j.tecto.2017.10.014, 2018.

Stüwe, K. and Schuster, R.: Initiation of subduction in the Alps: Continent or ocean?, Geology, 38, 175-178, https://doi.org/10.1130/G30528.1, 2010.

Tetreault, J. L. and Buiter, S. J. H.: The influence of extension rate and crustal rheology on the evolution of passive margins from rifting to break-up, Tectonophysics, 746, 155-172, https://doi.org/10.1016/j.tecto.2017.08.029, 2018.

Thöni, M.: Dating eclogite-facies metamorphism in the Eastern Alps - Approaches, results, interpretations: A review, Miner. Petrol., 88, 123-148, https://doi.org/10.1007/s00710-006-01535, 2006.

Thorwart, M., Dannowski, A., Grevemeyer, I., Lange, D., Kopp, H., Petersen, F., Crawford, W., Paul, A., and the AlpArray Working Group: Basin inversion: Reactivated rift structures in the Ligurian Sea revealed by OBS, Solid Earth Discuss. [preprint], https://doi.org/10.5194/se-2021-9, in review, 2021.

Trümpy, R.: Sur les racines helvétiques et les "Schistes lustr"es" entre le Rhone et la Vallée de Bagnes (Région de la Pierre Avoi), Eclogae Geol. Helv., 44, 338-347, 1951.

Trümpy, R.: La zone de Sion-Courmayeur dans le haut Val Ferret valaisan, Eclogae Geol. Helv., 47, 315-359, 1954.

Tucholke, B. E. and Sibuet, J. C.: Problematic plate reconstruction, Nat. Geosci., 5, 676-677, https://doi.org/10.1038/ngeo1596, 2012.

Tugend, J., Manatschal, G., Kusznir, N. J., Masini, E., Mohn, G., and Thinon, I.: Formation and deformation of hyperextended rift systems: Insights from rift domain mapping in the Bay of Biscay-Pyrenees, Tectonics, 33, 1239-1276, https://doi.org/10.1002/2014TC003529, 2014.

Tugend, J., Chamot-Rooke, N., Arsenikos, S., Blanpied, C., and Frizon de Lamotte, D.: Geology of the Ionian Basin and Margins: A Key to the East Mediterranean Geodynamics, Tectonics, 38, 2668-2702, https://doi.org/10.1029/2018TC005472, 2019.

Ustaszewski, K., Schmid, S. M., Fügenschuh, B., Tischler, M., Kissling, E., and Spakman, W.: A map-view restoration of the alpine-carpathian-dinaridic system for the early miocene, Swiss J. Geosci., 101, 273-294, https://doi.org/10.1007/s00015-0081288-7, 2008.

Van Hinsbergen, D. J. J., Vissers, R. L. M., and Spakman, W.: Origin and consequences of western Mediterranean subduc- 
tion, rollback, and slab segmentation, Tectonics, 33, 393-419, https://doi.org/10.1002/2013TC003349, 2014.

Van Hinsbergen, D. J. J., Spakman, W., Vissers, R. L. M., and van der Meer, D. G.: Comment on “Assessing Discrepancies Between Previous Plate Kinematic Models of Mesozoic Iberia and Their Constraints" by Barnett-Moore Et Al., Tectonics, 36, 3277-3285, https://doi.org/10.1002/2016TC004418, 2017.

Van Hinsbergen, D. J. J., Torsvik, T. H., Schmid, S. M., Maţenco, L. C., Maffione, M., Vissers, R. L. M., Gürer, D., and Spakman, W.: Orogenic architecture of the Mediterranean region and kinematic reconstruction of its tectonic evolution since the Triassic, Gondwana Res., 81, 79-229, https://doi.org/10.1016/j.gr.2019.07.009, 2020.

Vissers, R. L. M. and Meijer, P. T.: Mesozoic rotation of Iberia: Subduction in the Pyrenees?, Earth-Sci. Rev., 110, 93-110, https://doi.org/10.1016/j.earscirev.2011.11.001, 2012.

Vissers, R. L. M., Van Hinsbergen, D. J. J., Meijer, P. T., and Piccardo, G. B.: Kinematics of Jurassic ultra-slow spreading in the piemonte Ligurian ocean, Earth Planet. Sci. Lett., 380, 138-150, https://doi.org/10.1016/j.epsl.2013.08.033, 2013.

Vissers, R. L. M., Van Hinsbergen, D. J. J., van der Meer, D. G., and Spakman, W.: Cretaceous slab break-off in the Pyrenees: Iberian plate kinematics in paleomagnetic and mantle reference frames, Gondwana Res., 34, 49-59, https://doi.org/10.1016/j.gr.2016.03.006, 2016a.
Vissers, R. L. M., Van Hinsbergen, D. J. J., Wilkinson, C. M., and Ganerød, M.: Middle jurassic shear zones at Cap de Creus (eastern Pyrenees, Spain): A record of pre-drift extension of the Piemonte-Ligurian Ocean?, J. Geol. Soc., 174, 289-300, https://doi.org/10.1144/jgs2016-014, 2016b.

Von Blanckenburg, F. and Davies, J. H.: Slab breakoff: A model for syncollisional magmatism and tectonic in the Alps, Tectonics, 14, 120-131, 1995.

Wortel, M. J. R. and Spakman, W.: Subduction and slab detachment in the Mediterranean-Carpathian region, Science, 290, 1910 1917, https://doi.org/10.1126/science.290.5498.1910, 2000.

Wortmann, U. G., Weissert, H., Funk, H., and Hauck, J.: Alpine plate kinematics revisited: The adria problem, Tectonics, 20, 134-147, https://doi.org/10.1029/2000TC900029, 2001.

Yamato, P., Agard, P., Burov, E., Le Pourhiet, L., Jolivet, L., and Tiberi, C.: Burial and exhumation in a subduction wedge: Mutual constraints from thermomechanical modeling and natural P-T-t data (Schistes Lustrés, western Alps), J. Geophys. Res.-Sol. Ea., 112, https://doi.org/10.1029/2006JB004441, 2007.

Yamato, P. and Brun, J. P.: Metamorphic record of catastrophic pressure drops in subduction zones, Nat. Geosci., 10, 46-50, https://doi.org/10.1038/ngeo2852, 2017.

Zhou, X., Li, Z. H., Gerya, T. V., and Stern, R. J.: Lateral propagation-induced subduction initiation at passive continental margins controlled by preexisting lithospheric weakness, Sci. Adv., 6, 1-10, https://doi.org/10.1126/sciadv.aaz1048, 2020. 